\title{
Graphic correlation and sequence stratigraphy in the Palaeogene of NW Europe
}

\author{
J. E. NEAL ${ }^{1}$, J. A. STEIN ${ }^{2}$ \& J. H. GAMBER ${ }^{2}$ \\ 'Department of Geology and Geophysics, Rice University, PO Box 1892, Houston, TX 77251, USA. (Present Address: \\ Exxon Production Research Co., P.O. Box 2189, Houston, TX 77252, USA.) \\ ${ }^{2}$ Amoco Production Co., PO Box 3092, Houston, TX 77253, USA.
}

\begin{abstract}
A sequence stratigraphic analysis of well log, seismic, and biostratigraphic data has documented a pattern of cyclic sedimentation for the Palaeogene of the Central North Sea. Previously published research has also documented cyclic sedimentation related to sea level changes. Integrating Central North Sea subsurface sections with Palaeogene outcrop from NW Europe, using sequence stratigraphic first principles and the graphic correlation method, has produced a chronostratigraphic framework for the Palaeogene of NW Europe.

Northwestern Europe basins (London-Hampshire, Paris, and Belgian) have shallow marine to nonmarine environments, revealing basinward and landward facies shifts indicating sea level changes. The problem correlating NW Europe with North Sea deposits has been addressed by correlating a biostratigraphy to the deep water deposits outcropping in Denmark. Once a biostratigraphy joining the subsurface and outcrops is built, key bounding surfaces are correlated between basins. We find that: (1) sedimentation in the deep basin occurs as depositional pulses, separated by time-correlative biostratigraphic data terraces (hiatal intervals), which correspond to persistent seismic reflectors; (2) not all sequence boundaries are resolvable by graphic correlation, but the method brackets packages defined by seismic, log interpretation and biostratigraphy; and (3) correlation with outcrops reveals the true significance of the hiatal intervals. J. Micropalaeontol. 13(1): 55-80, September 1994.
\end{abstract}

\section{INTRODUCTION}

Hydrocarbon exploration in the Central North Sea has convoluted a standard stratigraphic nomenclature as consultants and exploration companies developed informal lithostratigraphic schemes with proprietary biostratigraphic information. An attempt at a standard lithostratigraphy was first published by Deegan \& Scull (1977). However, lithostratigraphy has been criticized for its inherent diachronaiety (Bertram \& Milton, 1988). Biostratigraphy has been used in recent lithostratigraphic work (Knox \& Cordey, 1992; Mudge \& Copestake, 1992) to trace different units, but these units remain diachronous, to varying degrees, because of the nature of lithostratigraphy (Bertram \& Milton, 1988; Stein et al., in press).

Fossil zonations have been widely used in the North Sea (e.g. Stewart, 1987; Powell, 1988; Gradstein et al., 1992). A detailed zonation scheme developed by Simon-Robertson Limited has been used by some authors (e.g. Timbrell, 1993) for correlation, however, this and many other zonation schemes (e.g. Den Hartog Jager et al., 1993) remain largely unpublished and difficult to tie to the published frameworks. The increased emphasis recently placed on individual biomarkers (e.g. Morton et al., 1993; Mudge \& Bujak, 1994) may have problems with reaching consensus on taxonomic designations between workers, using unpublished or rare species, and identifying environmentally depressed or reworked tops (Armentrout, 1991). The graphic correlation/composite standard method of biostratigraphy, integrated with geological and geophysical bounding surfaces, builds a consistent chronostratigraphic framework that mitigates these problems.

Superposition relationships, shifts in depositional environment, and major sedimentologic changes are critical when determining the sea level history of a particular location within the basin. However, correlating important surfaces with biostratigraphy is needed for temporal control that places local observations into a basinwide stratigraphic framework. A consistent biostratigraphy makes it possible to build a sequence stratigraphic framework that explains known deposits and suggests undiscovered ones. This paper discusses the role of the graphic correlation/composite standard biostratigraphic method in the construction of a sequences stratigraphic framework for the Palaeogene Central North Sea and connecting Northwest European basins.

\section{PREVIOUS STUDIES}

The stratigraphy of the lower Palaeogene section of the Central North Sea has evolved with the development of higher quality seismic data and numerous well penetrations since the first basinal studies of Parker (1975) and lithostratigraphic nomenclature of Deegan \& Scull (1977). Major field discoveries in the late 1960's and early 1970's focused mainly on structural traps. As the basin entered a more mature phase of development, emphasis shifted towards unravelling the stratigraphy represented in those fields. Rochow (1981) published the first seismic stratigraphic study of the North Sea 'Palaeogene', relating seismic units to the lithostratigraphic division of Deegan \& Scull 
(1977). Stewart (1987) followed with a 10-sequence division of the section, incorporating seismic and well data, tied to a biostratigraphic framework. Stewart's (1987) framework was related to tectonics by Milton et al. (1990), exploring the idea of nested high and low frequency sea-level change cycles.

Recently, a series of papers were published in a volume edited by Parker (1993) that cover a range of time scales and stratigraphic tools. Galloway et al. (1993) propose a tectono-stratigraphic framework for the entire Cenozoic and is the lowest resolution but most regional of these studies. Timbrell (1993) focuses on the Lower Eocene only and the stratigraphic complexity of the Balder and Frigg sections, while O'Connor \& Walker (1993) unravel the stratigraphy of the Lista/Sele Formation boundary within a sequence stratigraphic framework. Morton et al., (1993) use heavy mineral analysis along with biomarker stratigraphy to subdivide the section and Vining et al. (1993) emphasize palynofacies with respect to sea level changes. Den Hartog Jager et al. (1993) and Armentrout et al. (1993) present regional frameworks on a scale similar to our study, emphasizing the integration of seismic and well data. Other regional studies on the Palaeogene focus more on seismic geometries related to tectonics (Milton \& Jones, 1994) and biostratigraphic markers related to well log picks (Mudge \& Bujak, 1994).

\section{MATERIAL AND METHODOLOGY}

The correlations presented here come from an integration of the graphic correlation method of biostratigraphy (Shaw, 1964; Miller, 1977) with sequence stratigraphic principles (Vail et al., 1977; Posamentier \& Vail, 1988; Vail et al., 1991). A $7400 \mathrm{~km}$ seismic grid (Fig. 1) covers the study area and approximately 100 well logs tied by synthetic seismograms provide geologic information to supplement seismic facies analysis. Of those wells, 40 have detailed biostratigraphic reports and are part of the 150 wells with detailed biostratigraphy that were compiled to build a North Sea composite standard from Amoco's global composite standard (Stein et al., in press).

The composite standard is a chronostratigraphic range chart of all fossil appearances that occur in a series of stratigraphically overlapping reference sections, thus creating an ideal composite section for comparison with individual sections being studied. Figure 2 is a portion of the North Sea composite standard in the Upper Palaeocene/Lower Eocene showing the relationship between composite standard units (CSU) and the superposition

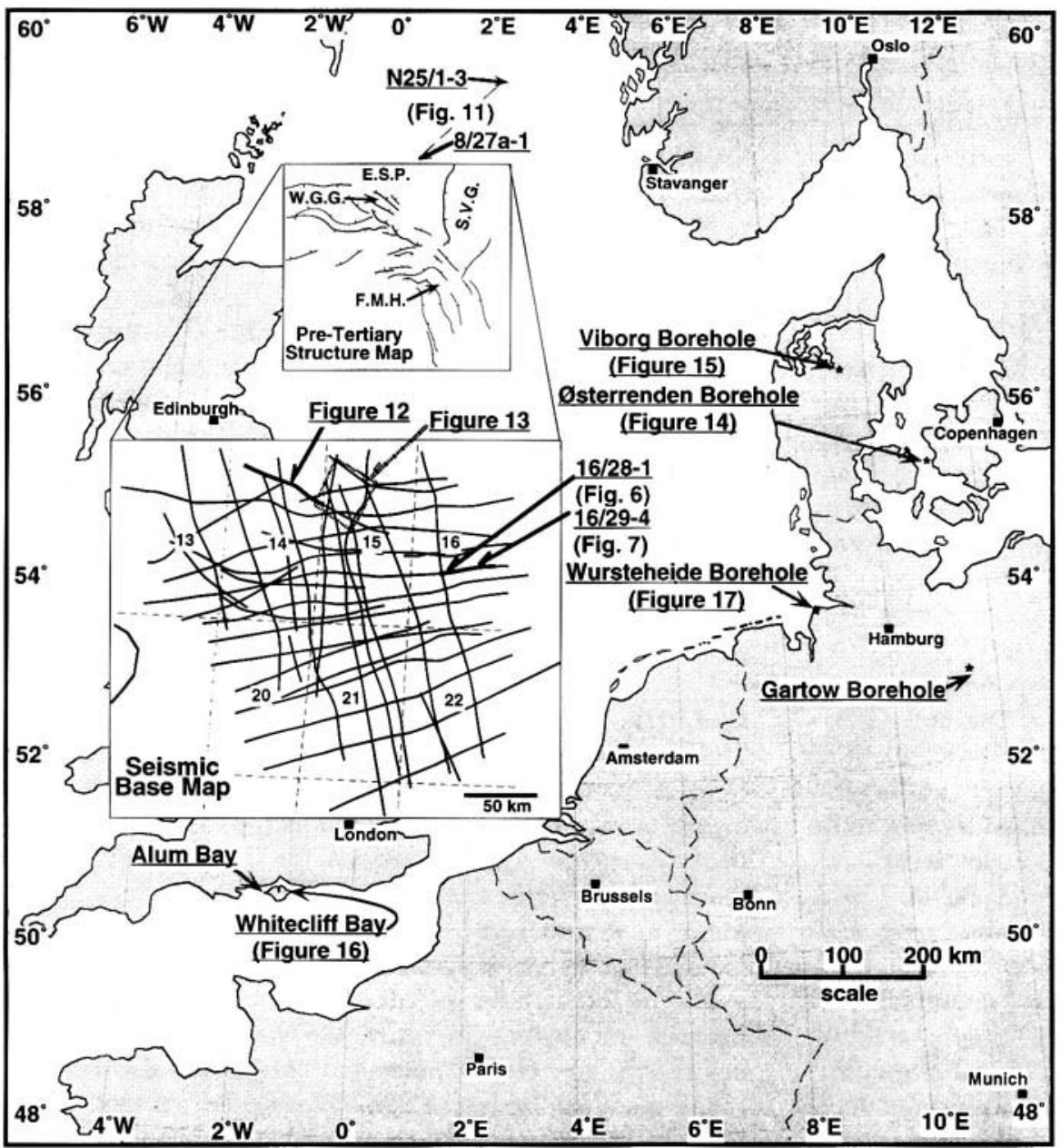

Fig. 1. Map of the northwestern Europe with the location of North Sea wells and seismic lines in addition to key outcrop and borehole sections. Labelled preTertiary structural elements are: E.S.P. = East Shetland Platform, W.G.G. = Witch Ground Graben, S.V.G. = South Viking Graben, \& F.M.H. = Forties-Montrose High. 


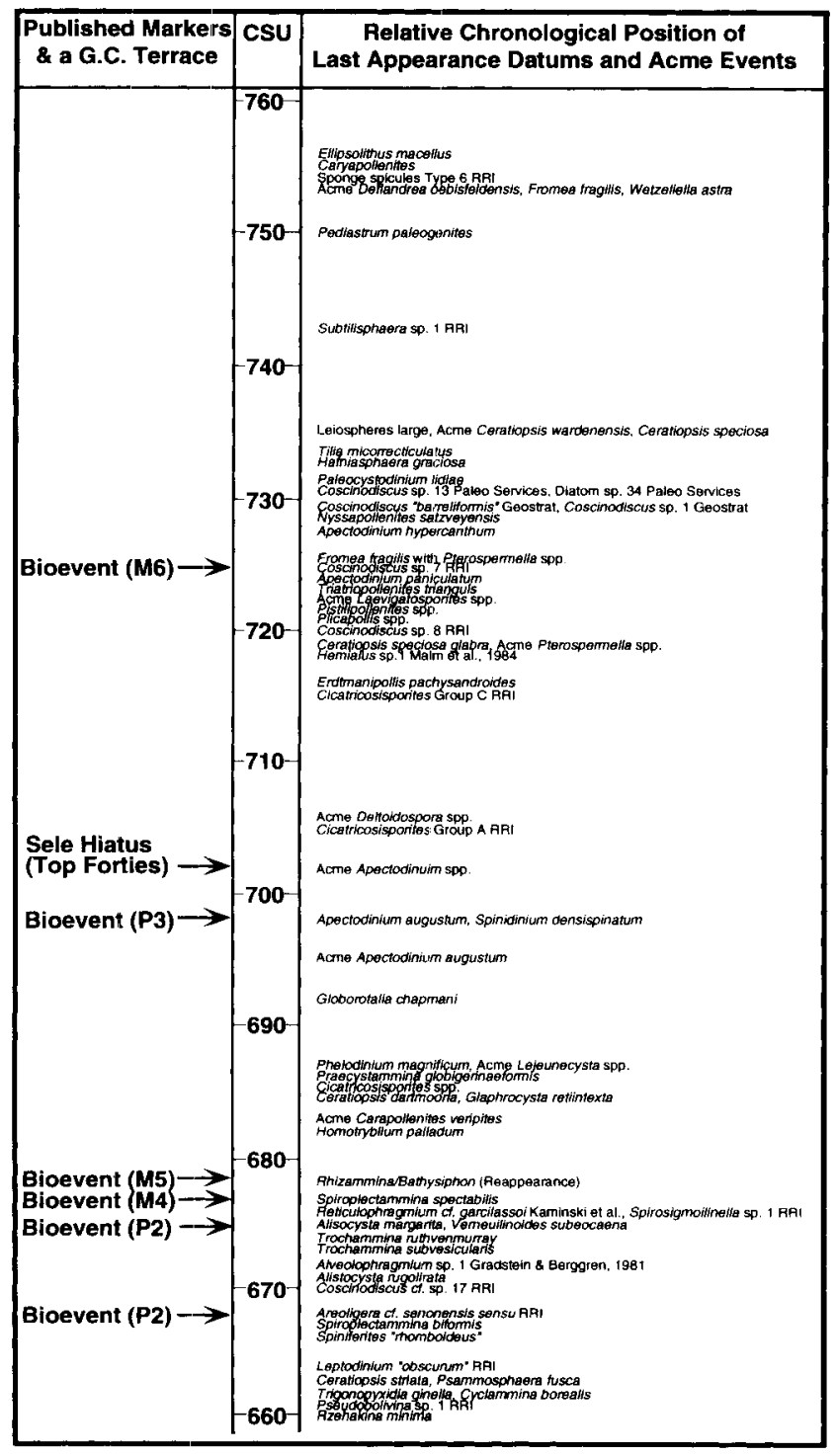

Fig. 2. Portion of the composite standard used in this study for the Upper Palaeocene and lowermost Eocene ages.

of various fauna. By creating $\mathrm{X}-\mathrm{Y}$ crossplots of a well or outcrop section against the composite standard, the biostratigrapher demonstrates graphically where stratigraphic gaps appear relative to the most complete section possible for the basin (Shaw, 1964; Miller, 1977). Stein et al.. (in press) describe in detail the necessary steps to build a composite standard for a specific basin. This process alters the global standard observed from other basins to account for taxa not globally recognized and for extended or shortened phylogenic ranges of taxa already in the global standard. Many well sections in a basin must be studied before a mature composite standard is produced. This ensures that depocentres of many ages are incorporated into the standard and lessens the chance of sampling bias. CSUs are nonlinear values that represent the chronological position of a fossil relative to others in the composite standard. Calibration of CSUs to various chrono- biostratigraphic charts (e.g. Haq et al., 1988; Harland et al., 1990) derives an absolute time value for the units. Regardless of the absolute time calibration, CSUs provide an indication of relative time and, therefore, relative rock accumulation (sedimentation) rates (Shaw, 1964).

A simplified example of the graphic correlation procedure is illustrated in Fig. 3. Graphic correlation interpretations start by plotting reported fossil tops by depth occurrence (vertical axis) against time in CSUs (horizontal axis). The scatter of points is then connected by an interpreted line of correlation (LOC), drawn with straight lines to honour the highest number of data points. The LOC approximates relative sedimentation rates (not accounting for differential compaction) as resolvable by the fossils. Interpretation of the biostratigraphy identifies at least two horizontal data terraces (sensu Shaw, 1964: 198), representing missing or condensed section, separating sloping line segments characteristic of higher depositional rates (Sediment Pulse). Also plotted are fossil tops occurring out of normal succession due to local conditions. These tops distort chronostratigraphic frameworks that are based only on key markers (Stein et al., in press). For example, fossil G plots above and to the left of the LOC, indicating an extended range or reworked occurrence. This observation has important implications for correlation of stratigraphic breaks. Fossil $\mathrm{G}$ is normally found above $\mathrm{F}$ and below $\mathrm{H}$, according to the chronostratigraphic range chart. In the example well, fossils $\mathrm{F}$ and $\mathrm{H}$ define a stratigraphic break that would normally contain the top of fossil G. If fossil G is regionally used as the key marker for this break, a significant amount of section falls within an incorrect chronostratigraphic unit (Fig. 3).

The geological meaning of a graphic correlation terrace is dependent on the depositional setting, data sampling and resolution of the biostratigraphic data. Graphic correlation terraces in a shallow marine setting have been shown to correspond to major unconformities or faults in lithified sections (Shaw, 1964; Miller, 1977). If the terrace is regionally extensive and time correlative in an unfaulted passive margin setting and separates younger from older sediments, it can, by definition, be identified as a sequence boundary or composite sequence boundary (Mitchum \& Van Wagoner, 1991). In a bathyal environment such as that illustrated in Fig. 3, the time represented by sandy 'fan' deposits is haif that contained within the intervening data terraces. This relationship is consistent with published sequence stratigraphic models that predict decreased sedimentation rates in the submarine fan setting during periods of relative rise, which occurs during lowstand prograding, transgressive, and highstand systems tracts (Vail, 1987; Posamentier \& Vail, 1988; Posamentier et al., 1991). In the Central North Sea, graphic correlation data terraces often occur within a single sample interval and may equate with over a million years of geologic time when calibrated to a chrono-biostratigraphic chart (e.g. Haq et al. 1988). Data terraces may also occur at sand-on-sand contacts in the submarine fan setting. These observations suggest that data terraces contain significant hiatuses, rather than simple condensed section. 

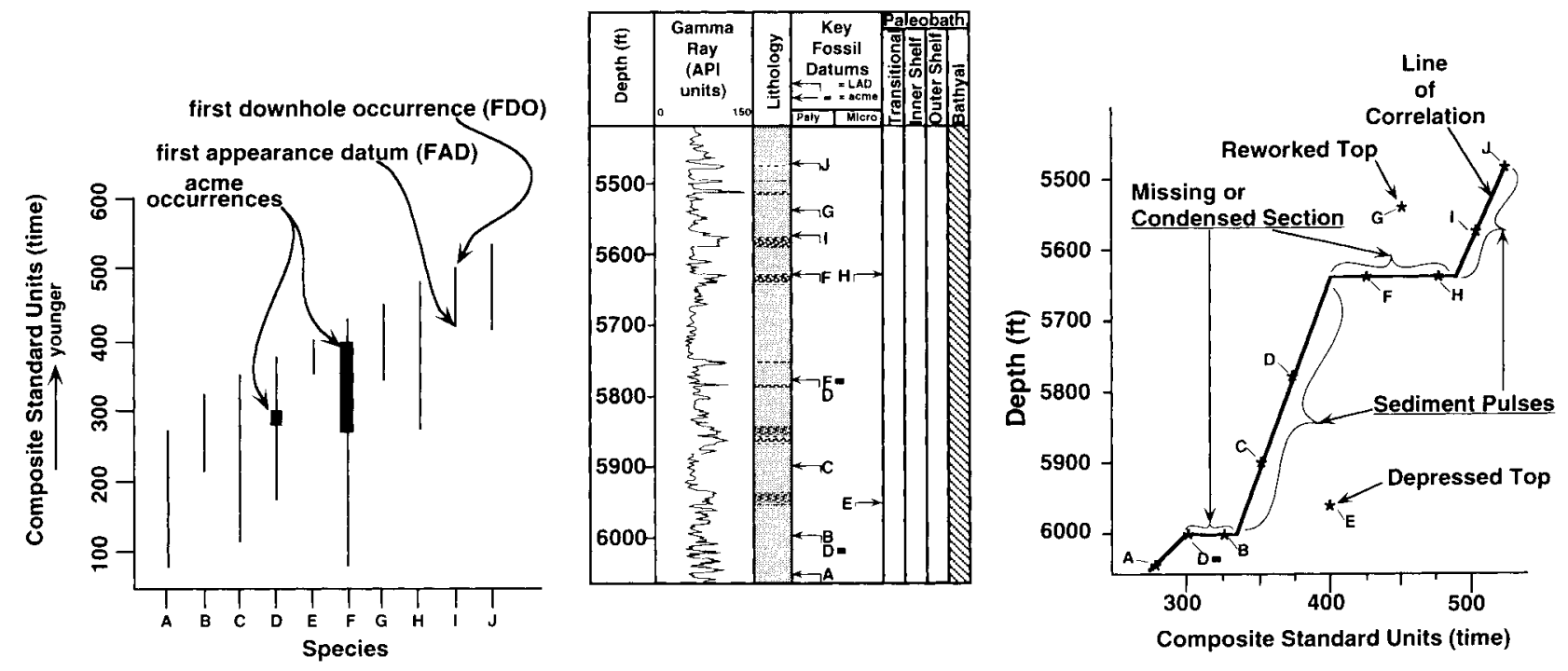

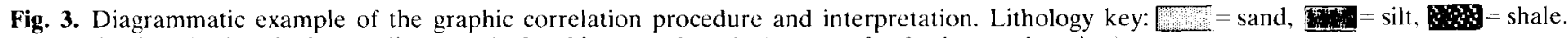
Composite Standard Units have a linear scale for this example only (see text for further explanation).

\section{Hiatal intervals}

Hiatus formation is a complex subject with many potential hiatus-forming mechanisms being only indirectly related to changing sea-level. For example, in continental slope and rise environments, hiatuses may be formed by slumping (Aubry, 1991), nondeposition, erosion, or dissolution (Pomerol, 1989). The indirect tie to sea-level links sediment supply in these environments to changes in shelfal accommodation space for sediments. Falling sea-level increases shelfal bypass of sediments, causing a pulse of sediment to be delivered to the slope (Posamentier et al., 1991). Rising sea level ponds sediment landward, starving the slope of sediments and increasing the potential for submarine erosion due to bottom current activity or dissolution. Key surfaces from different locations are correlated as resulting from a single event, if the hiatuses associated with each surface are shown to overlap in time (Aubry, 1991). Inherent uncertainties in the raw data must be considered when interpreting condensed sections or hiatuses. Biostratigraphic datums are most often picked from cutting samples taken at $30 \mathrm{ft} / 10 \mathrm{~m}$ intervals, but any given well may have larger data gaps due to drilling problems, barren samples, or lack of economic interest. These sample gaps may cause misplacement or apparent lengthening of a terrace (Shaw, 1964).

Figure 4 expands upon the major data terrace between $5600 \mathrm{ft}$ and $5700 \mathrm{ft}$ of Fig. 3 where different sedimentation rate histories may be interpreted from the same data. Using the condensed section approach of Loutit et al. (1988), continuous sedimentation at a greatly reduced rate occurs through the interval containing fossils $F$ and $H$. In this interpretation, no hiatus exists ('correlative conformity' of

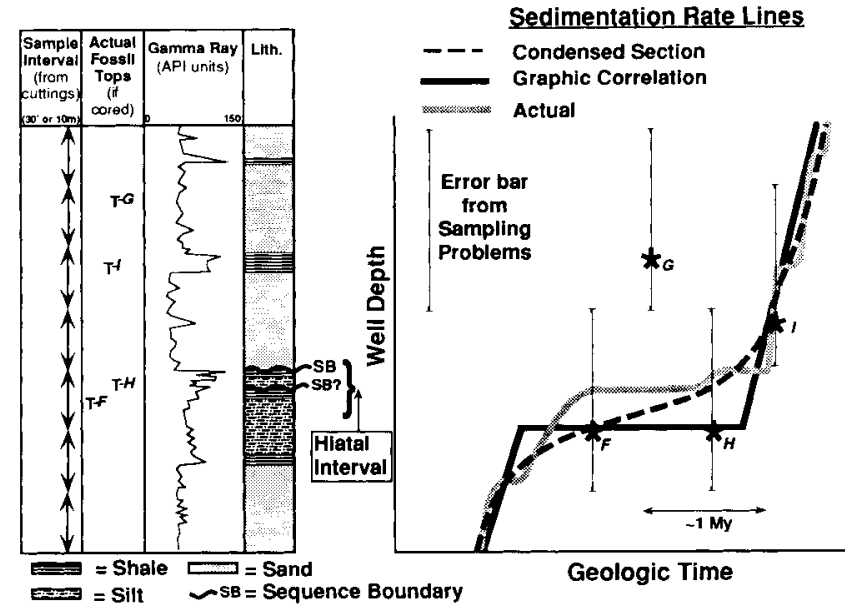

Fig. 4. Diagrammatic illustration of possible stratigraphic complexities (Actual line) around a hiatal interval with an interpretation of biostratigraphy from cuttings using grahic correlation and a condensed section approach. Data points are plotted at the base of each sample interval as they appear in standard well reports, the 'Actual' line is based on the exact position of each marker in a cored section (see text for discussion).

Mitchum et al., 1977), only greatly reduced continuous sedimentation represented by multiple fossil tops and a curvilinear sedimentation rate curve. Nondeposition is mentioned by Loutit et al. (1988), however, the possibility of a complex sedimentation history of deposition and erosion for slope settings (e.g. Aubry, 1991) is ignored.

A cored borehole, sampled in detail, will identify tops or last appearance datums (LADs) at a higher resolution than normal cutting samples (Fig. 4). The 'actual' sedimentation 
rate curve: is a subjective line based on LADs in the well as they would appear in a core and the relative sedimentation rate of turbidite sands versus hemipelagic drape (Kolla \& Macurda, 1988). The possible complexity around the tops of fossils $\mathrm{F}$ and $\mathrm{H}$ illustrate that neither the graphic correlation line nor the condensed section line accurately describe the depositional history. The graphic correlation line better approximates the episodic nature of these deposits, but is limited by data resolution.

Geologic time is represented in the rock record by either deposition or omission surfaces like unconformities or fault planes (Shaw, 1964). Graphic correlation data terraces represent some omission or condensation of section, as identified by the biostratigraphic resolution. We propose the use of 'hiatal interval' as a generic term for section where data resolution does not permit accurate partitioning of time represented by rocks and surfaces. Graphic correlation may identify a data terrace where sampling resolution is insufficient to accurately determine the geologic time duration represented by either the deposits or the omission surfaces within a package. A hiatal interval is different from a condensed section. Hiatal intervals infer the complex sedimentation and erosion history that may occur in hemipelagic sediments (Aubry, 1991), but requires resolution beyond that available from the sampling at hand to document. Hiatal intervals of this study represent significant time intervals and are correlative markers bracketing sequences. Condensed sections may occur in multiple positions within a sequence (e.g. top basin floor fan, top slope fan, or maximum flooding surface-see Vail \& Wornard», 1990), and may not represent a significant time interval. Hiatal intervals are identified from graphic correlation terraces. Terrace is a graphic correlation term, but hiatal interval can be used with or without graphic correlation as it describes rock units. Many sections interpreted as condensed may, in fact, be hiatal intervals and require further study to decipher their complexity.

Mitchum \& Van Wagoner (1991) identify high frequency sequence boundaries that result from the interference of high and low frequency sea level changes. While these events may be recognized in the shallow marine depocentres as hasinward shifts of facies, their expression in the decp marine setting is difficult to distinguish from normal autocyclic processes such as fan lobe avulsion. Long-term rises in sea-level partition more sediment in shelfal than basinal areas (Duval et al., 1992). Superimposed on long term rises are short term falls that can be recognized as facies shifts in the shallow section, but may or may not have expression in deep basin deposits. Correlation of basinal hiatal intervals with time-equivalent outcrop in Northwest Europe reveals that multiple sea-level changes may be identified in outcrop within the time span of a hiatal interval in the deep basin. The hiatal interval between $5600 \mathrm{ft}$ and $5700 \mathrm{ft}$ (Fig. 4) is an idealized example of this high frequency signal resolved in a basinal setting. During a long-term rise, sedimentation rates in the basin will decrease, potentially allowing submarine erosional processes to remove sediment that represents a long period of geologic time. Short-term sea-level falls, however, may result in minor pulses of sediment into the basin which are unresolvable with normal $30 \mathrm{ft}$ cutting samples (e.g. between top $\mathrm{F}$ and top $\mathbf{H}$ ). Without outcrop or core data that enable dense sampling of condensed sections, hiatal interval correlation is the most accurate means of separating sediment pulses in the deep marine setting, and identifying chronostratigraphic units.

\section{APPLICATION OF THE GRAPHIC CORRELATION METHOD}

The depositional sequences presented here borrow lithostratigraphic names from the lithostratigraphic frameworks of Deegan \& Scull (1977), Isaksen \& Tonstad (1989), Mudge \& Copestake (1992), and the Paleo-Services/Chevron framework of the Mid-Upper Eocene (Newton \& Flanagan, 1993). Figure 5 illustrates the correlation of depositional sequences used in the Palaeocene to Lower Eocene section to lithostratigraphic units from type wells of Mudge \& Copestake's (1992) and Isaksen \& Tonstad's (1989) frameworks. Also displayed here is a correlation to depositional sequences published by Stewart (1987), using his well sections and maps as tie points. The diachroneity of Stewart's (1987) sequences illustrates the need for a framework, founded on biostratigraphy, then tied to wells and seismic.

Sequences do not always correlate with their lithostratigraphic equivalents. Sequences are identified by their biostratigraphy and position on a graphic correlation LOC, related to surfaces on seismic and logs. As such, they are chronostratigraphic units and the same sequence may contain more than one lithostratigraphic unit. Describing a type $\log$ signature for any sequence is problematic as illustrated by the 'Upper Sele' sequence. This sequence typically has acme occurrences of the dinocysts, Cerodinium wardenense (Williams \& Downie, 1966) at its base and Deflandrea oebisfeldensis (Alberti, 1959) at its top. In type wells for each lithostratigraphic framework, these markers may be found together or separated, in the Balder Formation (tuffaceous claystone), Sele Formation (dark grey clay), Hermod Formation (deep water sandstone), or in their shelfal equivalent Beauly Formation.

A $30 \mathrm{~m}$ 'error bar' between the reported fossil depth occurrence and the well log pick was used by Armentrout et al. (1993), to account for operator consistency and seismic resolution. Using this margin of error allows great freedom in making a sequence pick fit the data. Generally, we tried to achieve precise agreement between at least two of the three disciplines used in this study (log interpretation, palaeontology, and seismic interpretation). The error bar mentioned by Armentrout et al. (1993) is one way to reconcile a mistie of biostratigraphy with well $\log$ and seismic interpretation. When sequences are below seismic resolution or occur within a seismically chaotic zone, well $\log$ interpretation and fossils are the only tools that allow correlation with any confidence.

Sequences are picked on individual well logs based on an interpretation of the relative sea-level signal for each particular location, correlated with biostratigraphy. For example, in deep water settings, the base of the Upper Sele sequence occurs at a high gamma marker on electric logs 


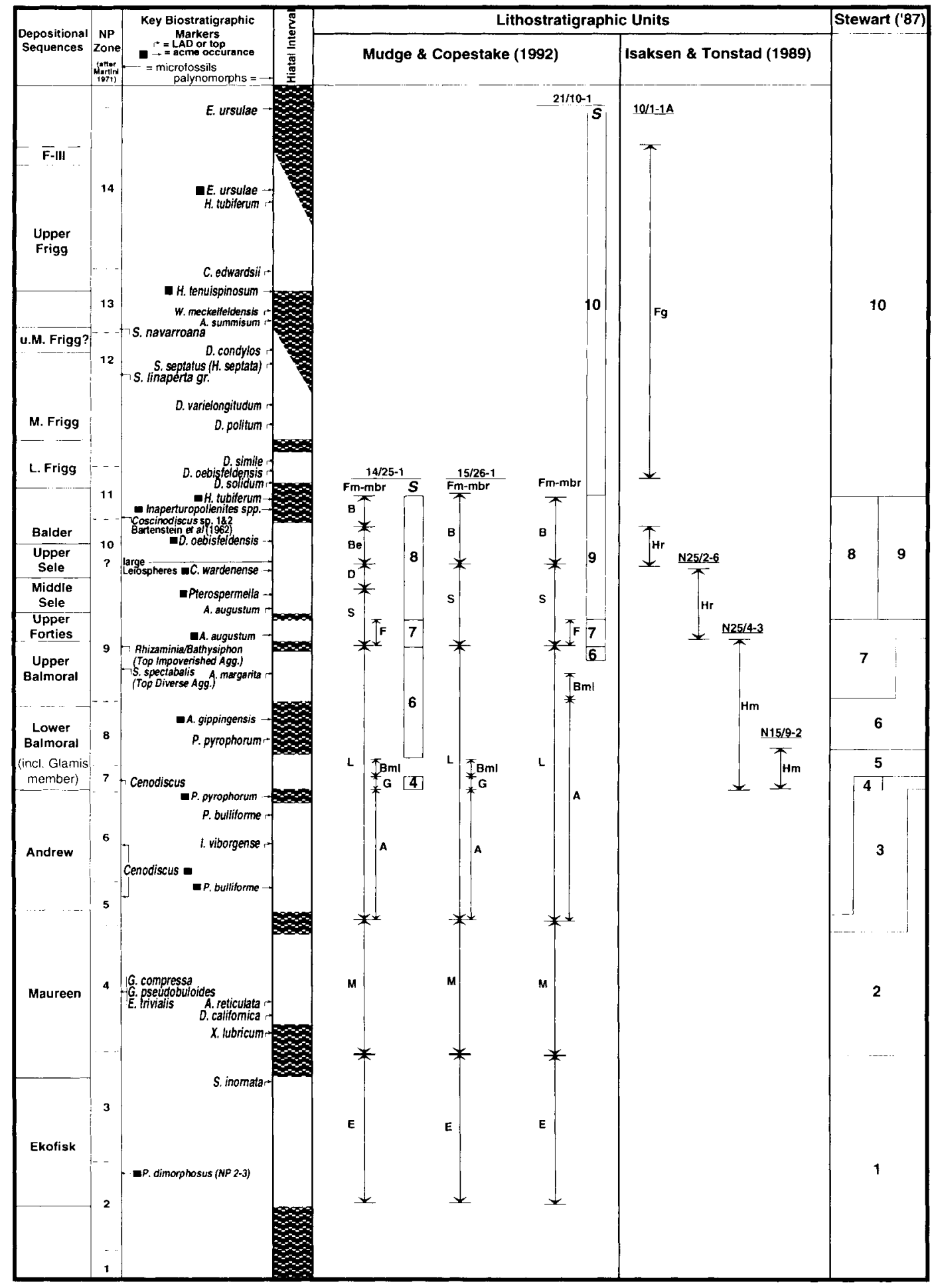

Fig. 5. Correlation of depositional sequences, key biostratigraphic markers, and hiatal intervals with namesake lithostratigraphic units from

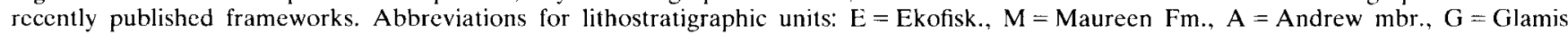
mbr., Bal $=$ Balmoral mbr., $\mathrm{L}=$ Lista Fm., $\mathrm{S}=$ Sele Fm., $\mathrm{F}=$ Forties mbr., $\mathrm{D}=$ Dornoch mbr., Be $=\mathrm{Beauly} \mathrm{Fm} ., \mathrm{B}=\mathrm{Balder}$ Fm., Fg $=$ Frigg Fm., $\mathrm{Hr}=$ Hermod Fm., Hm = Heimdal Fm. Also shown are Stewart's (1987) sequences: $S=$ type section for the scquencxe (see text for discussion). 
near the reported acme occurrence of $C$. wardenense from cuttings. The sequence boundary is interpreted to be combined with the underlying maximum flooding surface. The sequence boundary marks renewed basinal deposition due to a fall in relative sea-level and shelfal bypass, depositing sediment containing abundant $C$. wardenense, capped by hemipelagic drape containing abundant $D$. oebisfeldensis. In shelfal settings, the sequence boundary occurs at the base of a thick coal, an incised valley deposit, or at the base of a transgressive sandstone. These deposits may overlie a high gamma shaly section interpreted to represent periods where sediment is ponded in a coastal system to the west. The coal represents the remains of a marsh and a base level zero datum (Milton et al., 1990). Thick, rooted coals are indicators of transgression (Cross, 1988), therefore, their bases are likely exposure surfaces. Not all coals overlie sequence boundaries, however, as the Balder sequence (Beauly Formation) contains many coals that are discontinuous and simply reflect delta lobe abandonment within an overall transgressive package.

\section{Deep water environment example of graphic correlation}

The composite standard for the Central North Sea has been largely built and utilized in the deep marine environment where correlation of turbidite packages relies on good biostratigraphy. A sequence stratigraphic interpretation involves a series of steps that begins with interpretation of the biostratigraphic data, followed by picking sequences on the well logs that are tied to seismic with synthetic seismograms, and finally correlated with seismic between well control points. Figure 6 is a typical basinal well for the North Sea Palaeogene with gamma ray curve, lithology and the biostratigraphic top or acme datums from a well report. Plotted to the right of the well are biostratigraphic datums at their reported depth and relative age within the composite standard for the Central North Sea (in nonlinear composite standard units). A LOC is interpreted with the scatter of points. Since the composite standard for the North Sea was built using North Sea wells, individual wells are plotted against the standard in later iterations minus the well itself, to avoid a circular interpretation.

Where graphic correlation identifies a hiatal interval, it is possible to place a sequence boundary on well logs at, or near the interval, using the $30 \mathrm{~m}$ 'error bar'. Sequence boundary picks come directly from well log interpretation of key surfaces, aided by integration of palaeobathymetric and biochronological information. Often, high gamma shales are used to pick genetic sequences (Galloway, 1989; Stewart, 1987). These high gamma intervals, which are interpreted to represent very slow sedimentation, divide the section stratigraphically into sediment pulses. In a basinal well, sequence boundaries are picked at the base of each sediment pulse. In the deep marine environment, this approach is possible because highstand and transgressive deposits are not well represented and result in merged sequence boundaries and maximum flooding surfaces (Vail, 1987). However, in a sand-rich turbidite environment such as the Palaeogene Central North Sea, submarine scouring may produce a sequence boundary in wells that is locally a sand-on-sand contact. Choosing a log marker to designate as the sequence boundary must rely on the biostratigraphy. Unfortunately, not all $\log$ and seismic sequences were resolvable with the graphic correlation tool. However, data terraces served to bracket sequences that are picked on the basis of seismic and well evidence (e.g. Sele sequences are correlated between the Top Forties and Balder Hiatal Intervals).

A basinal well $15 \mathrm{~km}$ to the east is interpreted in the same manner as Fig. 6 to correlate sequences and demonstrate how sediment distribution within sequences changes (Fig. 7). The Lower Balmoral sequence ( $2475 \mathrm{~m}$ and $2775 \mathrm{~m}$ ) in Fig. 6 is a thick stack of sandy turbidites that becomes a thinner, silty interval in Fig. 7. The Maureen sequence sands of Fig. 7 between $8870 \mathrm{ft}$ and $9130 \mathrm{ft}$ are calcareous claystone in Fig. 6 $(2850 \mathrm{~m}-2825 \mathrm{~m})$. Additionally, the Top Forties terrace in Fig. 6 merges with the Upper Lista terrace in Fig. 7 , demonstrating a longer stratigraphic break in the LOC of Fig. 7 at the top of the Upper Balmoral sequence. Individual biomarkers defining each sequence may vary slightly. Fossils that define a sediment pulse in one well may be found in hiatal intervals above or below the sequence in another well, but the markers should not define a sediment pulse for a different sequence (e.g. the acme of Paleocystodinium bulliforme (Ioannides, 1986) is within the sediment pulse of the Andrew sequence in Fig. 7, but occurs in the hiatal interval below the sequence in Fig. 6). Individual markers are found in different sequences if they occur out of normal succession (i.e. the LOC does not pass through them - see Fig. 3 for example). This is one advantage graphic correlation has over stratigraphic frameworks based solely on individual markers.

Plotting both graphs together with the same horizontal (time) scale highlights time-correlative stratigraphic breaks (Fig. 8). For example, 16/28-1 and 16/29-4 both show data terraces from 860 to 910 CSU. Both wells experience condensed sedimentation or erosion during that period, which demonstrates a correlative break in rock accumulation. Major breaks may contain more than one data terrace as shown at location A (Fig. 8). Even time intervals of small correlative breaks (i.e. location B, Fig. 8) identify depositional sequences, regardless of lateral facies changes. Figure 8 also brings out the variable nature of rock accumulation between the correlative terraces in time and space. In a submarine fan setting, sedimentation is complex and varies greatly in depositional rate along strike and dip (Walker, 1978). Where both wells share a time interval of no rock accumulation, the overlapping data terraces are interpreted to represent correlative events bracketing sediment pulses. Regional correlation is necessary to verify that the stratigraphic breaks are basinwide events. Deposits between terraces do not necessarily have to overlap in time due to the episodic nature of the depositional setting. The different lengths of terraces between wells is explained by considering fan lobe avulsion and its effects on a LOC.

Tying the well data to a seismic line with synthetic seismograms is a critical step in supporting correlations, since seismic reflectors follow geologic time lines (Vail et al., 1977). Plotting the LOC of a well next to the time-converted 


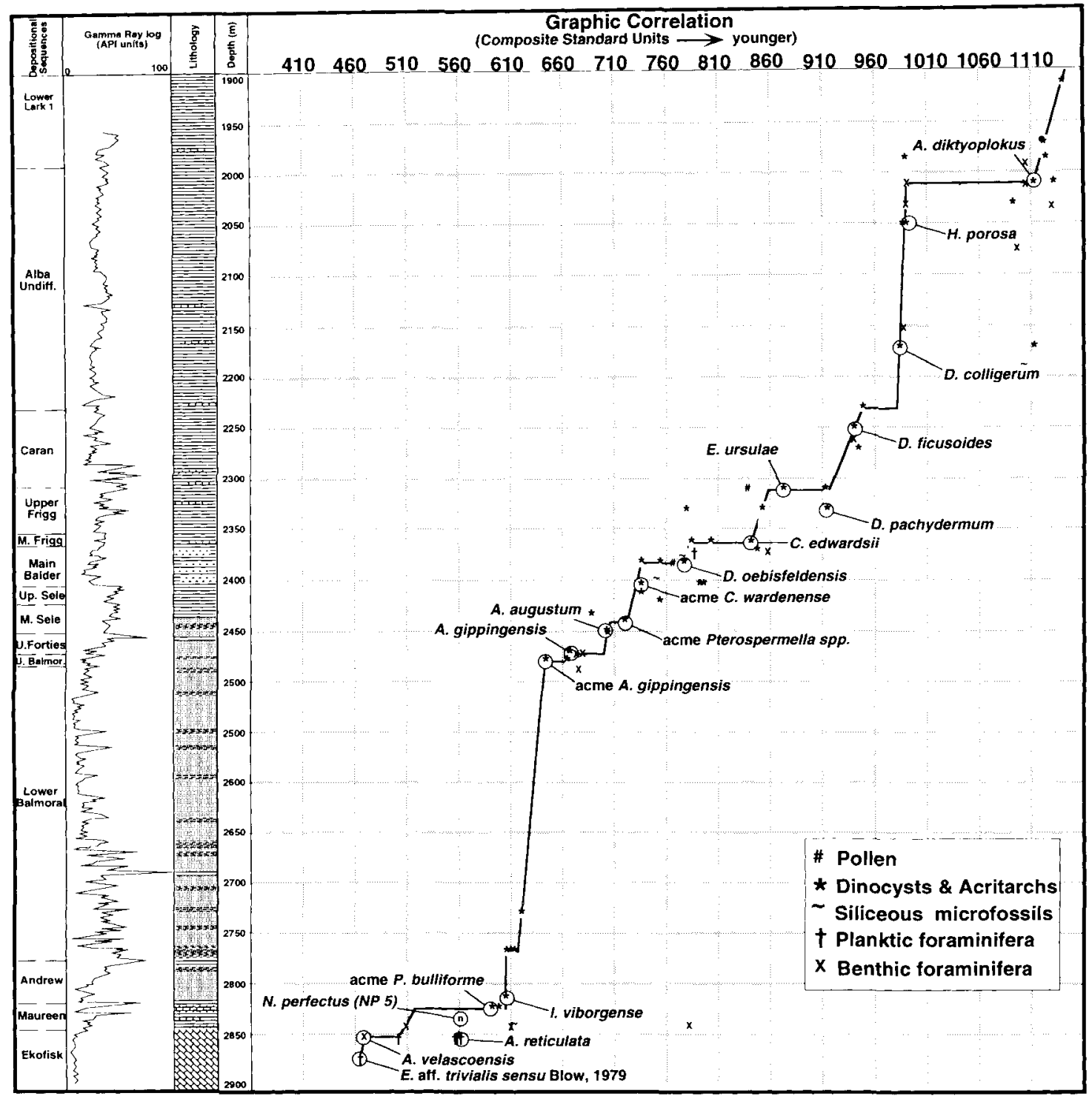

Fig. 6. Graphic corelation and sequence stratigraphic interpretation of UK wcll 16/28-1. Data points are first downhole and acme ocurrences of various taxa, distinguished by symbol. Palacobathymetry is given as bathyal and open marine for the entire section (palaeobathymetry estimates courtesy S.P.T.-Robertson Research). Lithology symbols: limestones, $=$ chalk,

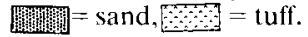

gamma ray curve directly ties relative geologic time, as resolved by the biostratigraphy, to a seismic line (Fig. 9). This plot provides information concerning the variable duration of geologic time represented within the seismic section. Hiatal intervals correlate, within resolution limits, to regionally mappable seismic reflectors. Figure 9 illustrates that some intervals are below the resolution of this seismic data and are represented by a single wavelet peak or trough. These intervals are correlated on wells until a thicker section permits seismic resolution.

Sequences that are distinguishable on seismic data show remarkable lateral facies and thickness variation. Figure 10 illustrates how the seismic, well, and biostratigraphic correlations are integrated to resolve complex lobe deposition in two dimensions. The seismic line shows complex stratal termination patterns associated with deposits in a submarine fan setting (Posamentier et al., 1991). Correlations of well and biostratigraphic data help construct a sequence stratigraphic model highlighting the potential for multiple stratigraphic traps. Sandy turbidite depositional sequences, sourced from the west and depositionally pinching out to the east have considerable proven reserves for various Palaeocene sequences (e.g. Sarg \& Skjold, 1982; O'Connor \& Walker, 1993). 


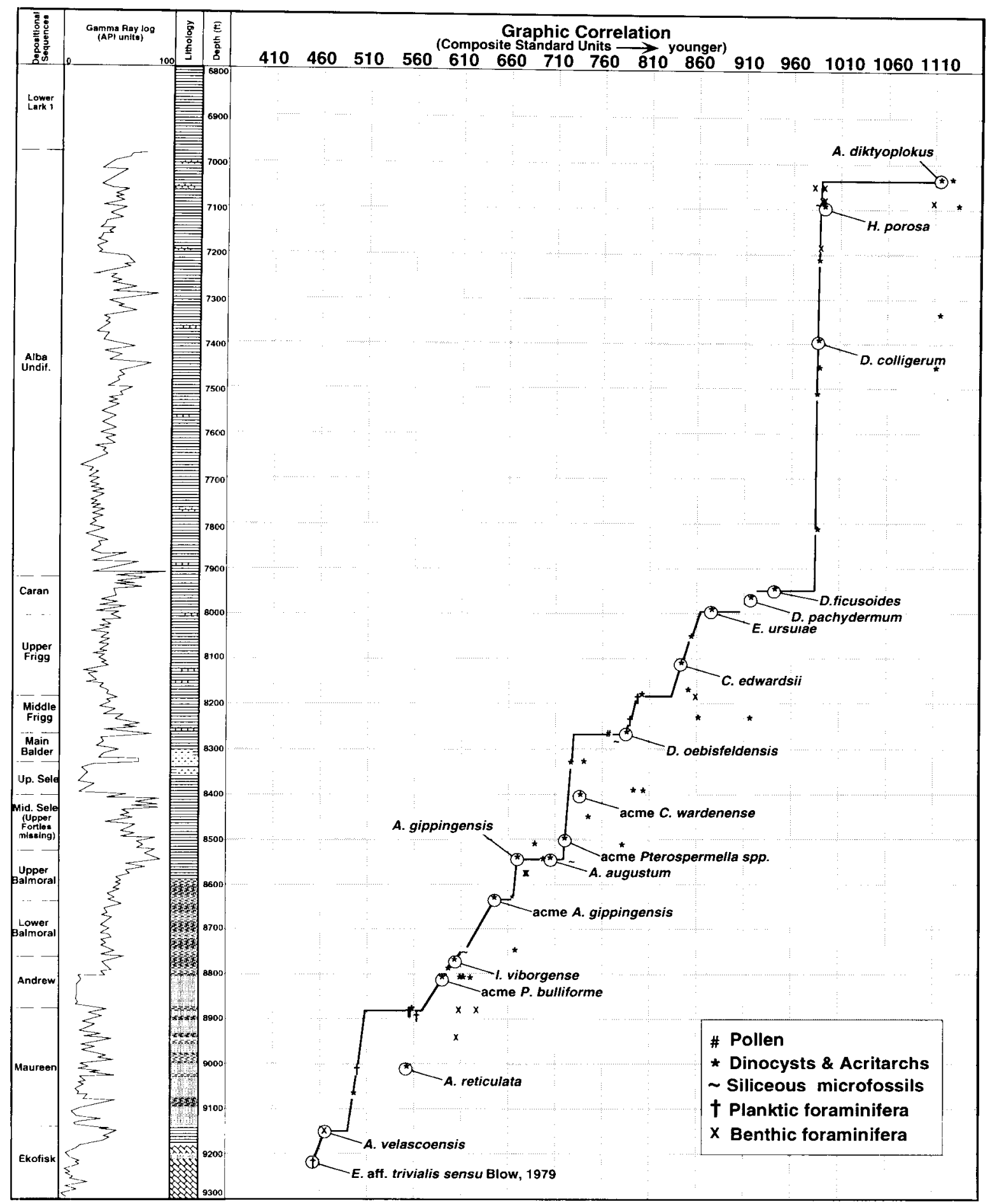

Fig. 7. Graphic correlation and sequence stratigraphic interpretation of UK well 16/29-4. Data points first downhole and acme occurrences of various traxa, distinguished by symbol. Palaeobathymetry is given as bathyal and open marine for the entire section (palaeobathymetry

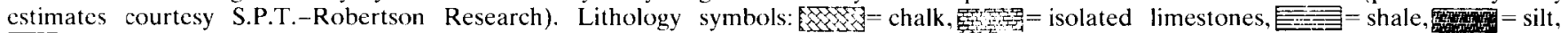
$\square=$ sand,,$=$ tuff. 


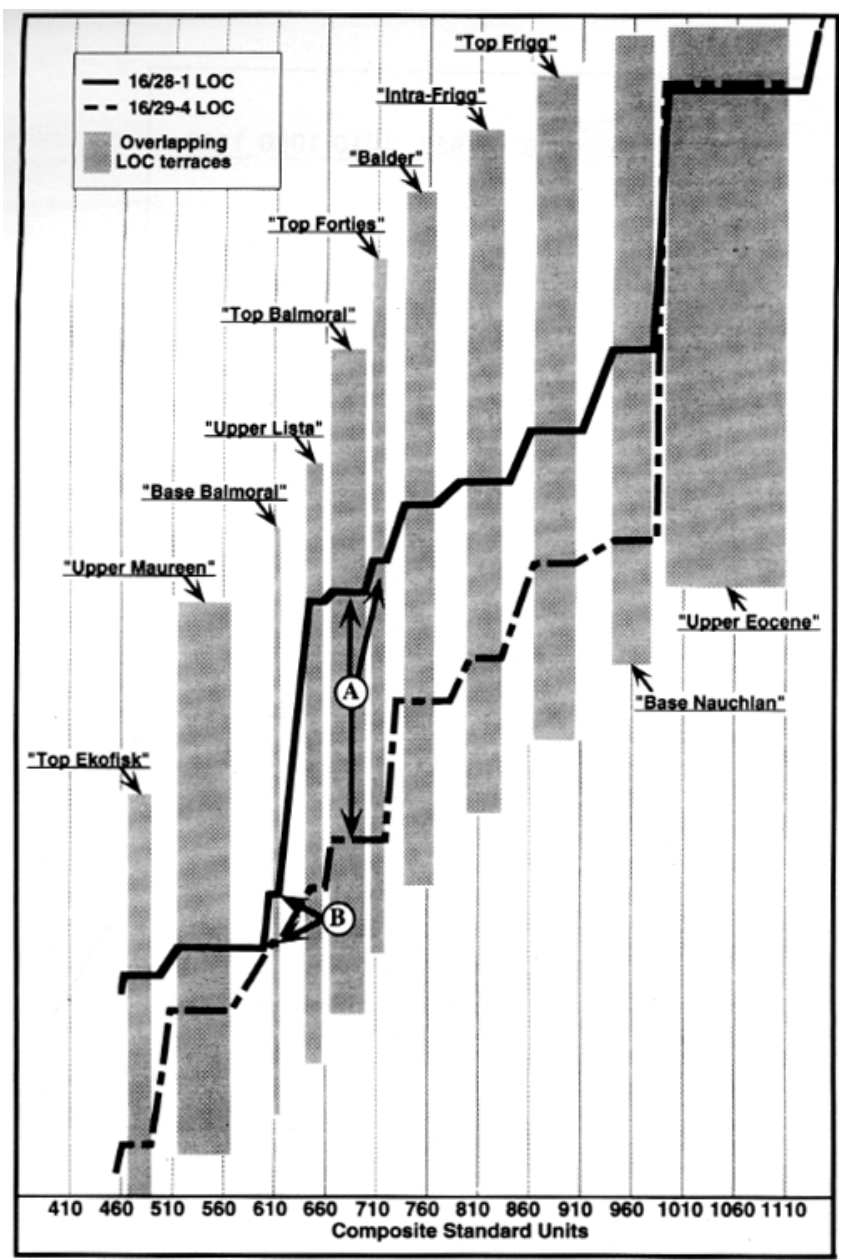

Fig. 8. Composite graph of line of correlations for two Central North Sea wells with overlapping time gaps indicated. Location (A) shows the collapse of two offsets into one and location (B) shows corelation of cven duration events (see text for further discussion).

\section{SHELF TO BASIN CORRELATION OF THE UPPER PALAEOCENE AND LOWER EOCENE}

The 'top Palaeocene' seismic reflector is recognized by Rochow (1981) as a regional marker associated with the top of the tuffaceous claystones of the Balder Formation and the widespread coals of the Beauly Formation. This marker corresponds to the base of Stewart's (1987) Sequence 10, which is shown to be thin and at the limit of seismic resolution within the mapped area. The LAD of the dinocyst Eatonicysta ursulae (Morgenroth, 1966) marks the top of Sequence 10. Due to the high concentration of red-stained planktonic foraminifera, Stewart interprets this sequence as representing pelagic sedimentation similar to that recorded in the Røsnæs Clay of Denmark (HeilmannClausen et al., 1985), conditions brought about by high relative sea levels resulting from the collapse of the Palaeocene Scottish uplift (Milton et al., 1990). The top of Sequence 10 represents a regional unconformity which is 'baselapped' (Stewart, 1987) by younger Eocene sediments produced by renewed tectonism (Galloway et al., 1993; Jones \& Milton, 1994).

Interpreting the entire lower Eocene North Sea section as an interval of sediment starvation overlooks age-equivalent (E. ursulae palynomorph zone of Stewart, 1987) depocentres that are found in the Witch Ground Graben and Frigg field areas. Lower Eocene shelf deposits are penetrated in UK Quadrant 8 on the East Shetland Platform by the Shell/Esso $8 / 27$ a-1 well (Fig. 11). This well is important for two reasons: (1) the Lower Eocene section has shallow water deposits and displays basinward shifts of facies; and (2) biostratigraphy indicates that the shallow shelf deposits from approximately $2700-2300 \mathrm{ft}$ are age-equivalent or younger than the Frigg deep sea fan (Fig. 11). Two depositional sequences are recognized in the shallow water section of $8 / 27 \mathrm{a}-1$, which are below graphic correlation resolution between data terraces above the Upper Forties and Balder sequences. The thick coals at $3100 \mathrm{ft}$ and $2870 \mathrm{ft}$ represent the remains of a transgressive marsh, a zero base level datum, and are found over a large region of the Outer Moray Firth Basin (Milton et al., 1990). These coals are interpreted as deposits directly overlying sequence boundaries. The coal at $3100 \mathrm{ft}$ and the increasing-upward gamma ray sand that is capped by a thin marine shale of the Middle Sele Sequence represent a transgressive systems tract and maximum flooding surface in this well with the decreasingupward gamma sand being the highstand systems tract, the top of which is a sequence boundary below the second major coal. Lowstand deposits of this Middle Sele Sequence are seen in well N25/3-1, which has a palaeobathymetry in the upper bathyal (zone 4, Fig. 11) range. Age correlation shows the Middle Sele Sequence in both sections to have rest on chronologically-overlapping Top Forties terraces on each LOC. Directly overlying the Middle Sele Sequence in the $8 / 27 \mathrm{a}-1$ well is the second major coal that is capped by mudstones containing the Balder Hiatal Interval. Correlation to the deep basin reveals a thin unit above the Middle Sele Sequence, but below the Balder Hiatal Interval. This additional sequence is also unresolvable with graphic correlation, but is associated with a reported acme occurrence of $C$. wardenense.

Although no major shift in palaeobathymetry is indicated around $2720 \mathrm{ft}$ in $8 / 27 \mathrm{a}-1$ (zone 1 to zone 2), graphic correlation indicates a significant gap associated with the acme occurrence of Inaperturopollenites spp., which is the Balder terrace. Likewise, a data terrace around $2250 \mathrm{ft}$ that has little palaeobathymetric evidence from fossils for a deepening is associated with the top of E. ursulae - the same marker that caps the Frigg Fan (Heritier et al., 1980). Correlation of sections between these two chronologicallyoverlapping hiatal intervals demonstrates that the shallow shelf deposits of $8 / 27 \mathrm{a}-1$ from $2250 \mathrm{ft}$ to $2720 \mathrm{ft}$ are roughly the same age as the Frigg submarine fan (Fig. 11), and define a lower Eocene regressive pulse. A more precise correlation is made possible by sequence stratigraphic methods with the aid of graphic correlation. The Frigg regression has been divided into three sequences in Fig. 11 with a possible fourth sequence, Frigg-III, recognized by 


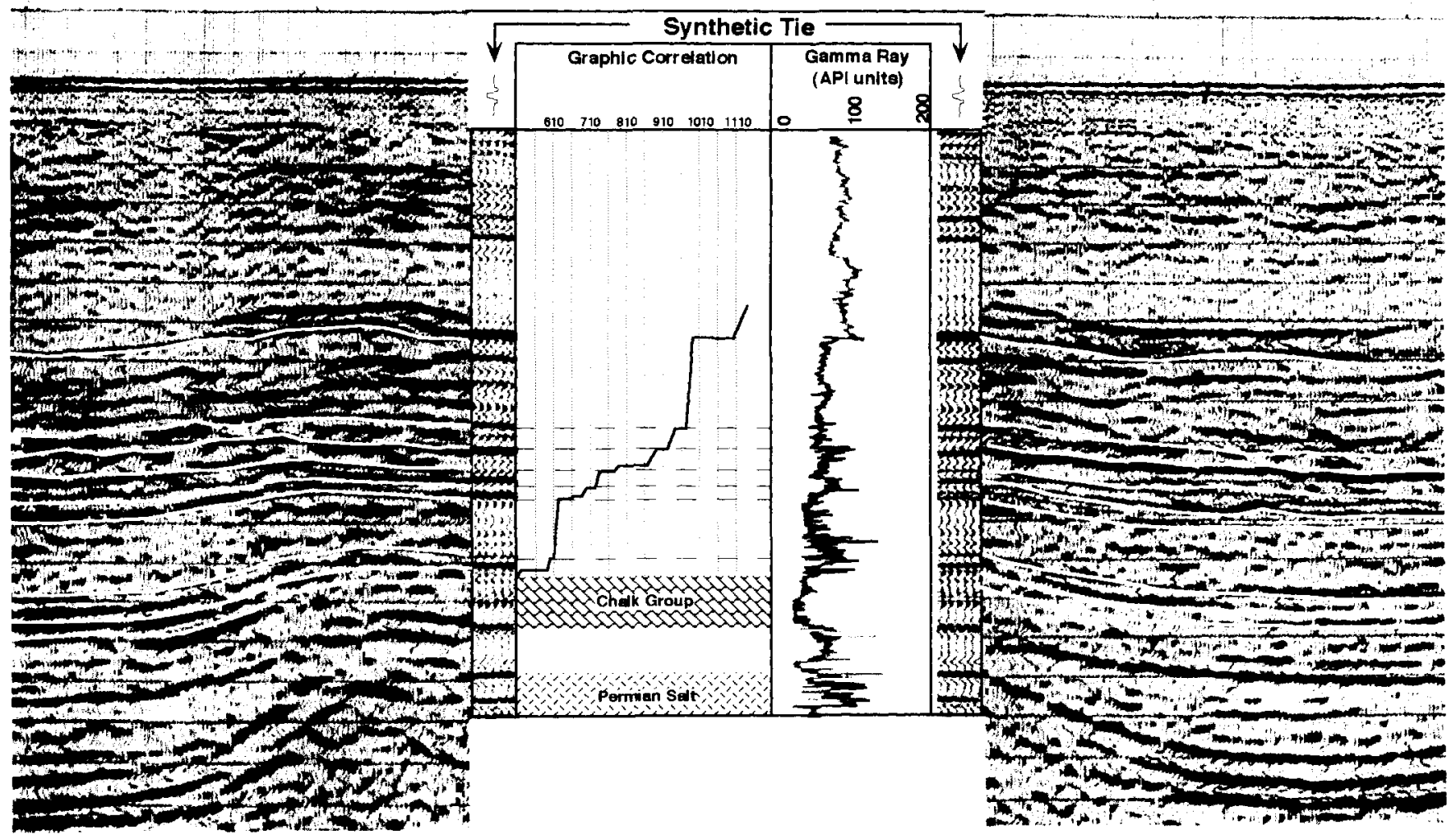

Fig. 9. Synthetic seismogram tie of the UK 16/28-1 well (Fig. 6) to a regional seismic line. Graphic correlation and gamma log are time/depth converted to tie with the seismic data. This display illustrates how relative geologic time can be directly tied to seismic time. Sce Fig. 6 for correlation of sequences as some sequences are below seismic resolution (see text for further discussion). Seismic data are courtesy of GECO-Prakla and Nopec.

Mudge \& Bujak (1994), which appears to correspond to the upper sequence of the Tay Fan in UK Quad 21 (Den Hartog Jager et al., 1993). The Lower Frigg Sequence is characterized by the tops of dinocysts $D$. oebisfeldensis and Dracodinium solidum (Gocht, 1955). The top of this sequence is a minor terrace here associated with Dracodinium politum (Bujak et al., 1980). Graphic correlation comparison suggests that this sequence is missing in $8 / 27 \mathrm{a}-1$. The Middle Frigg Sequence is picked on the N25/1-3 well at the base of a thick sand near the top of the Frigg fan. This sequence contains the tops of Spiniferites septatus (Cookson \& Eisenack, 1967), Apectodinium summissum (Harland, 1979) and starts at the top of Dracodinium varielongitudum (Williams \& Downie, 1966). By graphic correlation, this sequence is equivalent to the lower part of the section between the Balder terrace $(2720 \mathrm{ft})$ and the Top Frigg terrace $(2250 \mathrm{ft})$ in $8 / 27 \mathrm{a}-1$. The top of this sequence in $\mathrm{N} 25 / 1-3$ occurs near CSU 810 . When the $810 \mathrm{CSU}$ value is plotted on the line of correlation for $8 / 27 \mathrm{a}-1$, its depth value intersects the well at approximately $2650 \mathrm{ft}$. A thin glauconitic sand is found at this depth in the well and marks the top of the Middle Frigg Sequence in 8/27a-1, even though none of the diagnostic marker fauna for the sequence were found. Conversely, the Upper Frigg Sequence in 8/27a-1 has diagnostic forms of Kisselovia edwardsii (Wilson, 1967) and the acme occurrence of
Homotryblium tenuispinosum (Davey \& Williams, 1966), which occur in a single sample that also has the top $E$. ursulae at the top of the Frigg section in N25/1-3. This grouping of markers in one sample suggests that the Upper Frigg Sequence found in 8/27a-1 is missing in N25/1-3. Graphic correlation demonstrates a longer Top Frigg terrace in N25/1-3 than in 8/27a-1, indicating a longer time gap in the basinal well.

\section{Nested stratigraphic cycles on seismic and in graphic correlation}

Recognition of a lower Eocene shelf in seismic data from the Outer Moray Firth area is complicated by the presence of high amplitude, discontinuous reflectors that represent the coaly coastal plain deposits of the Beauly Formation. These sediments also represent the transgressive phase of the upper Palaeocene-lowermost Eocene regression/ transgression cycle that thickens to the west. A single seismic line in the east-central part of Quadrant 14 (Fig. 12, see Fig. 1 for location) displays a distinct progradational package downlapping onto the Beauly coal reflectors. Tracing this package to adjacent lines, these sediments fill erosional topographic lows in the Beauly seismic facies. The top of the prograding wedge and its lateral equivalent is a major downlap surface for the next regressive pulse in the middle Eocene, and likely represents 

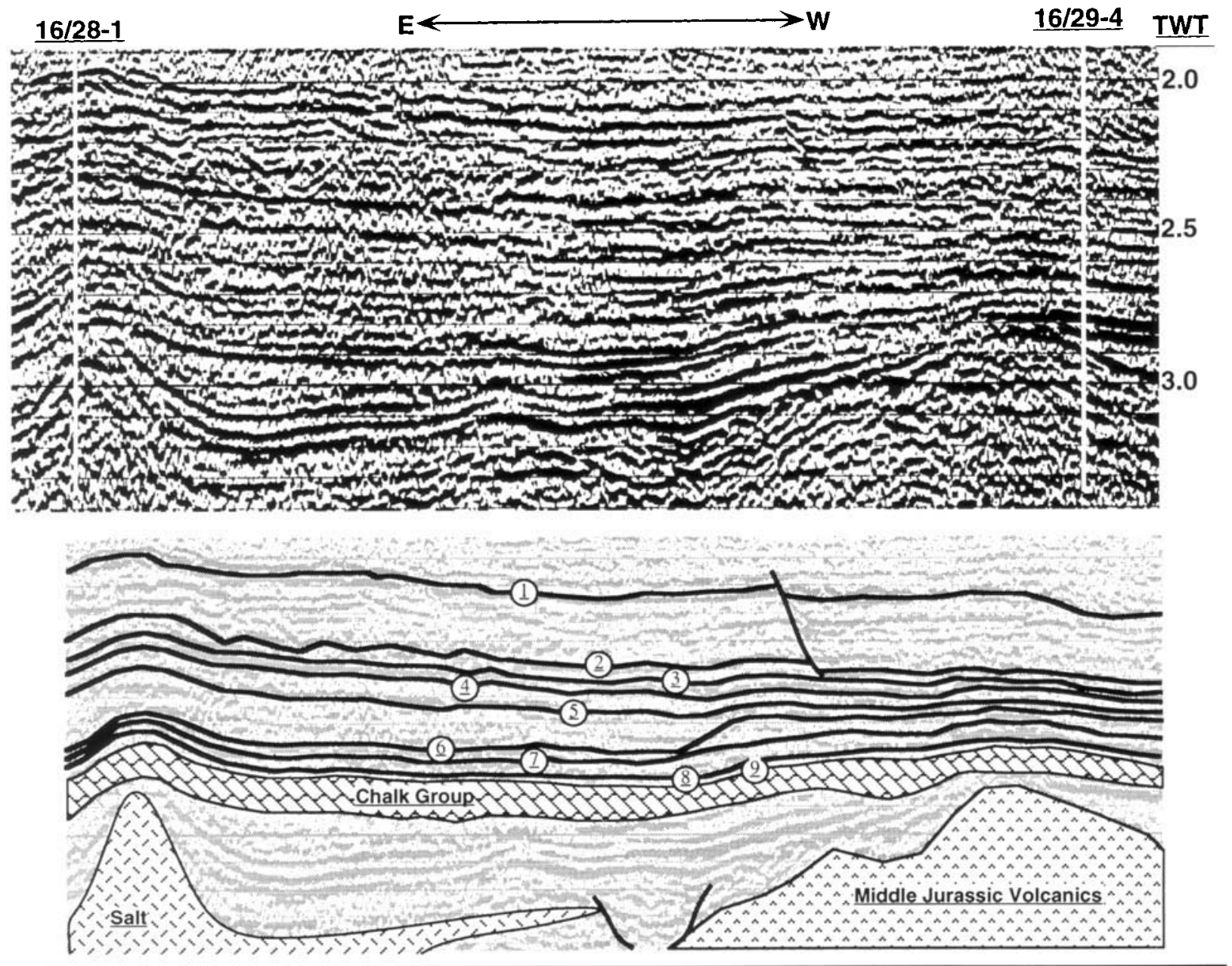

$16 / 28-1$

$16 / 29-4$

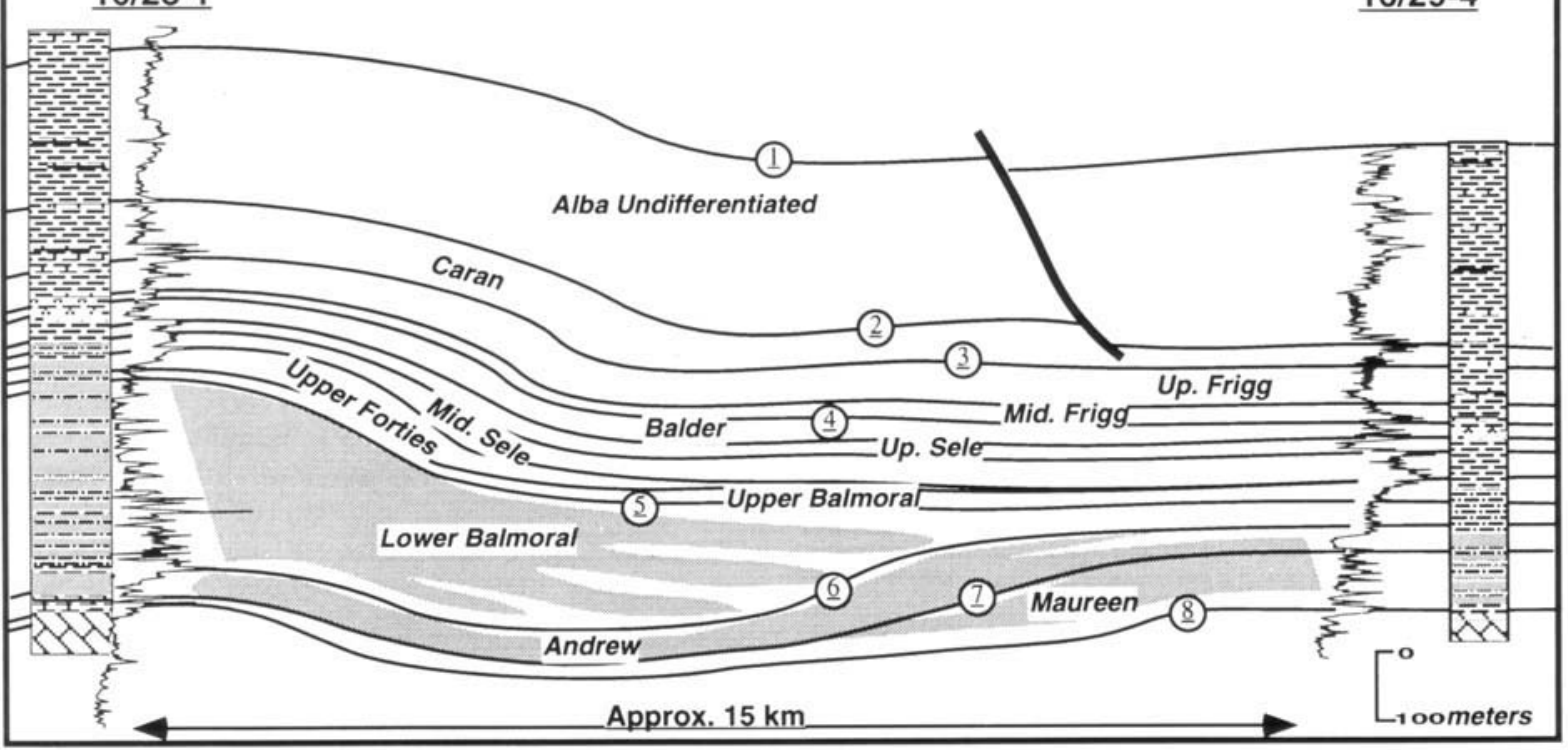

Fig. 10. Seismic and well $\log$ cross-section between $16 / 28-1$ and $16 / 29-4$, illustrating the rapid lateral facies shifts that are seen in this area. Numbered sequence boundaries that start with 9. (K/T boundary) on the interpreted seismic are displayed in the geologic cross-section. Between sequences 3., 4., \& 5. are additional sequences, identified and correlating surfaces. Scismic data courtesy of GECO-Prakla \& Nopec. 


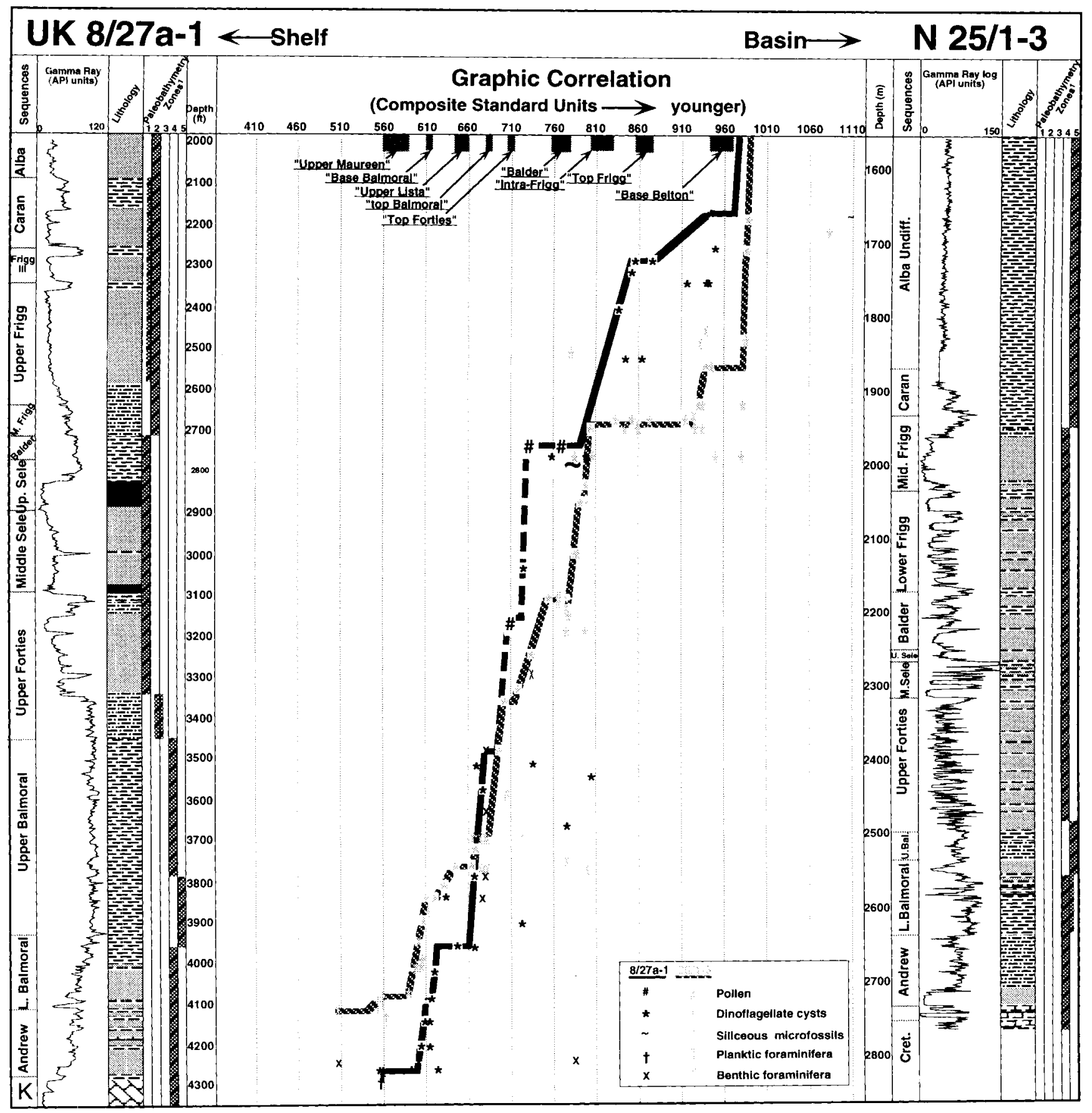

Fig. 11. Composite plot of graphic correlation comparing the shelfal UK 8/27a-1 and basinal (Frigg Field) N25/1-3 wells with overlapping LOC terraces from these wells and Fig. 11 shown at the top. Lithology key: $\mathbf{E A}=$ Cretaceous limestone, frot $=$ isolated limestone, $=$ sand, upper bathyal; 5. middle to lower bathyal (courtesy of S.P.T.-Robertson Research).

the top of Stewart Sequence 10. The wedge and time equivalent sediments downlap and onlap the Beauly and are traced with well control to condensed (hiatal) intervals that cap these lowermost Eocene coals. Where this drape facies is found, the middle Eocene regression directly downlaps onto the Beauly seismic package or its time-equivalent Balder reflector.

A striking feature of Fig. 12 is the throughgoing reflector (trough) just above 1.0 seconds. This marker represents a coaly section above the base Balder sequence boundary. 

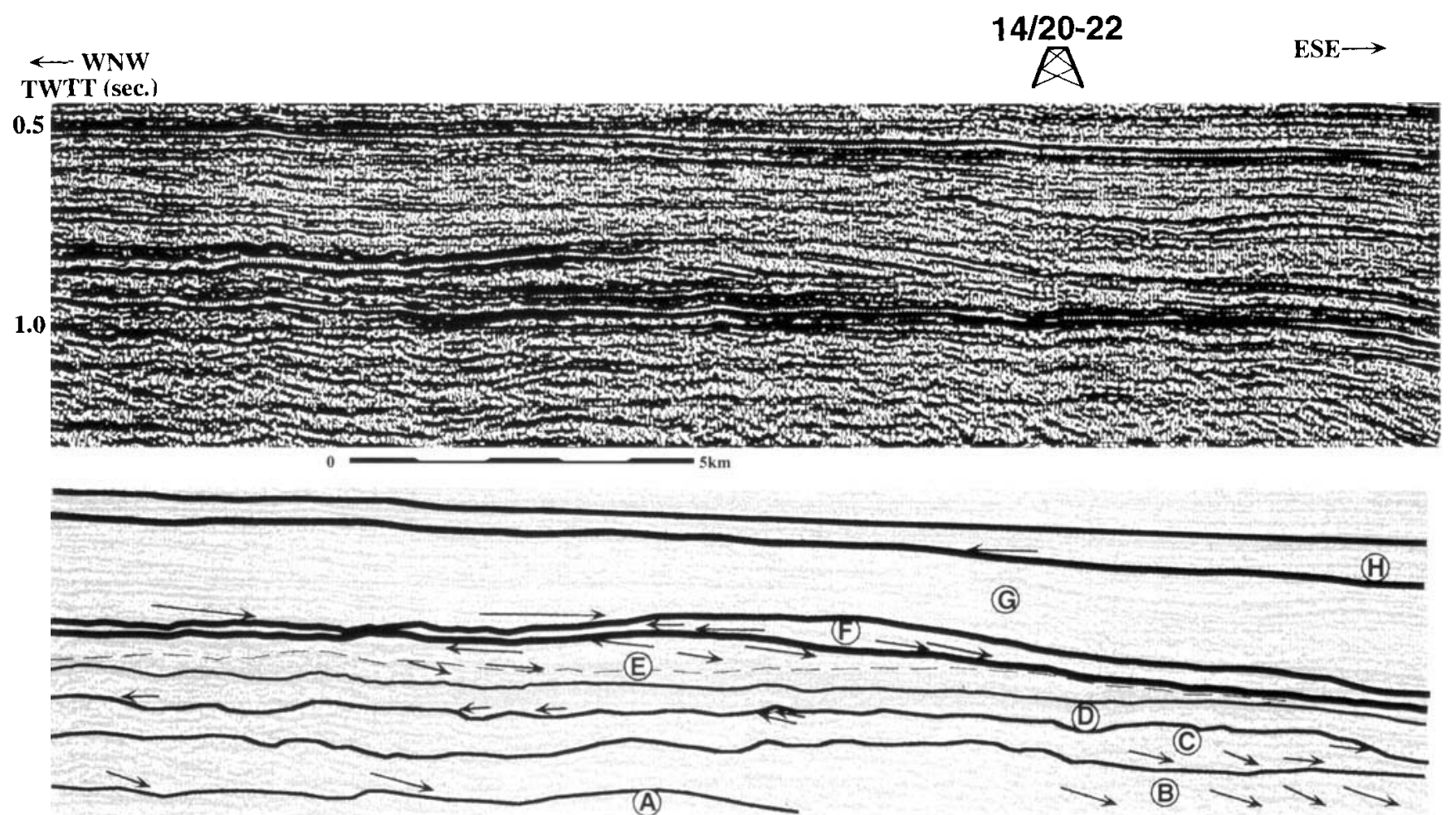

Fig. 12. Seismic expression of the mid-lower Eocene regressive shelf. Labelled features are: A. Upper Balmoral sequence; B. Upper Forties sequence; C. Middle Sele sequence; D. Upper Sele sequence; E. Main Balder sequence; F. Frigg Regression (undifferentiated); G. Nauchlan sequence; H. Lower Lark 1 sequence. Stratal terminations are highlighted with small arrows - $\longrightarrow$. Note the backstepping units within the Balder sequence separately by a transgressive surface (dashed line -- ). Third order boundaries $=-$, second order boundaries $=-$. Seismic data are shown courlesy of SPT (Horizon Geophysical).

The Balder sequence has internal downlap surfaces indicating the backstepping of sediment packages and the transgressive nature of this sequence. Above the backstepping units is a strong reflector that is onlapped and downlapped by the thin prograding package. When traced to wells with biostratigraphic reports that are tied to seismic by synthetics, this reflector corresponds to a mudstone representing a rapid deepening (inner/outer shelf to upper bathyal in one sample interval) and a graphic correlation terrace (Balder hiatal interval).

This small-scale shelf has a facies distribution similar to the more extensive Palaeocene-lowermost Eocene shelf. Note the high amplitude peaks at the left of the prograding package that lose strength moving right. These seismic facies are interpreted as a coastal plain (left) to shoreface/mouth bar (right) transition, mirroring similar transitions within the Beauly and progradational Dornoch Formation. For this reason, care must be taken when picking the 'top Palaeocene' reflector to ensure proper chronostratigraphic correlation. Even when depositional dip lines are used, this pick is made possible only by directly tying the biostratigraphic data to seismic with synthetics.

Other wells in UK Ouadrant 15 also encounter lower Eocene deep water sands and silts that are capped by a marker shale (Top Frigg hiatal interval) containing the LADs of E. ursulae and Hystrichosphaeridium tubiferum (Ehrenberg, 1838) and overlie another marker shale (Balder hiatal interval) with acme occurrences of $D$. oebisfeldensis and Inaperturopollenites spp. Figure 13 is a cross-section through this depocentre in the Witch Ground Graben. Composite graphic correlation plotting demonstrates two major hiatal intervals bracketing a Ypresian sediment pulse. Correlation lines through the cross section indicate depositional sequences that are carried with and between the overlapping terraces on graphic correlation. The cross section highlights major transgressive/regressive cycles that bundle depositional sequences. Regressive phases represent most of the sediment and transgressive phases represent major hiatal intervals (Lista, Balder, Top Frigg, and Upper Eocene). Well $14 / 20-22$ in the cross section ties to the seismically identified shelf of Fig. 12 just downdip of the prograding package. Correlation to the other wells demonstrates the position of this wedge between the Balder and Top Frigg terraces.

\section{CORRELATION TO NW EUROPE OUTCROPS AND BOREHOLES}

Tying sequence boundaries in the Central North Sea to outcrop sections and cored boreholes in Northwest Europe is a critical step in testing and refining a palaeogeographic model for the entire Palaeogene North Sea Basin. The first step toward this goal required a good biostratigraphy tie of the Central North Sea to outcrops and boreholes described in NW Europe. The best place to start this tie is the 

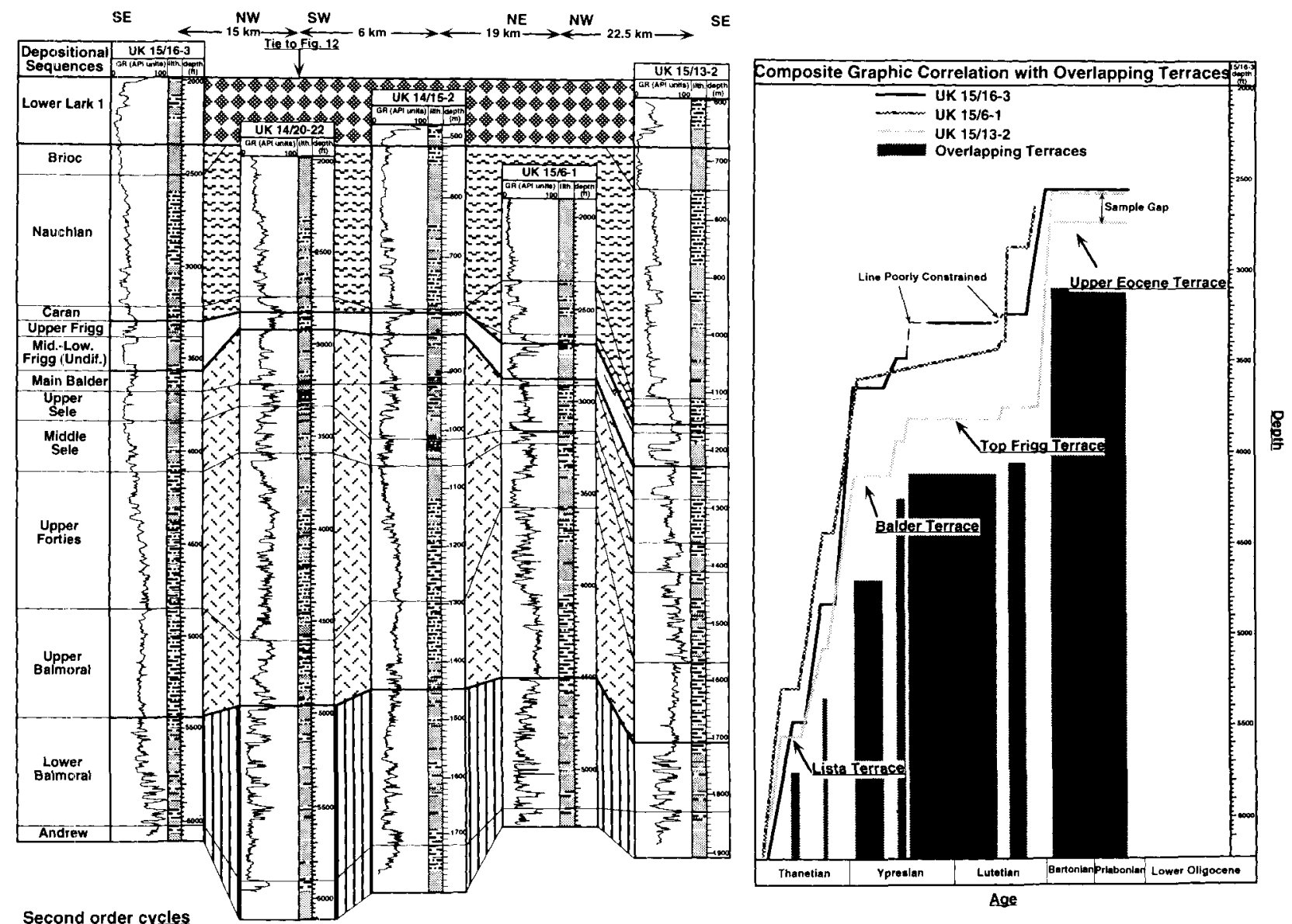

WII Lower Paleocene Regression 6 Upper Paleocene Regression

$\square$ Lower Eocene Regression

Upper Middle Eocene Regression Lower Oligocene Regression

Fig. 13. Stratigraphic cross-section through the Witch Ground Graben area of the Central North Sea (see Fig. 1 for location). A composite graphic correlation display of three of the five logs with detailed biostratigraphic reports highlights the second order transgressions that bracket multi-sequence pulse is bathyal, while the Upper Palaeocene shallows to inner shelf and transitional. The next two regressions are deposited in outer shelf/upper bathyal depths, with UK 15/6-1 having an inner shelf Upper Middle Eocene section (see text for discussion). Palaeobathymetry estimates are from S.P.T. (Robertson Research).

Danish/North German section, as it consists of mainly deep water marls and claystones with a highly detailed dinoflagellate and nannofossil stratigraphy (HeilmannClausen et al., 1985; Michelsen et al., in press). Using the mature composite standard built in the Central North Sea, data were graphed from the Viborg 1 borehole (HeilmannClausen, 1985), the D.G.I. $83101 \emptyset_{\text {sterrenden borehole }}$ (Nielsen et al., 1986) and the Wursterheide borehole (Heilmann-Clausen \& Costa, 1989). Bases (FADs) of fauna are added to the plots to improve resolution and incorporate additionall information. Bases in the North Sea composite standard are carried as the lowest (oldest) downhole appearance of any particular fossil. Generally, bases are an unreliable stratigraphic tool in areas where ditch cuttings are the primary data source because of the problems of cavings. Lines of correlation are drawn mainly with respect to faunal LADs, as is the case in the North Sea, for consistent correlations to the Central North Sea.

\section{Osterrenden borehole}

The first borehole graphed using the Central North Sea Composite Standard is the Danish Geotechnical Institute 83101 borehole (Nielsen et al., 1986) at $\emptyset$ sterrenden (see Fig. 1 for location). The line of correlation is interpreted with six data terraces (Fig. 14). The chronological position of some of the overlapping hiatal intervals from North Sea wells is included in Fig. 14 to relate $\emptyset$ sterrenden terraces to the subsurface framework. A good overlap correlation appears for five of the terraces with a possible overlap on the sixth. The Top Frigg correlation is less reliable due to its occurrence within the last sample, as fossil ranges may extend upwards in a more complete section. As the top of $E$. ursulae is indeed the LAD of this marker in Denmark (Nielsen et al., 1986: 247), perhaps the Top Frigg terrace is correlated correctly. With this correlation, depositional sequences from the North Sea can be tentatively tied to the section described by Nielsen et al. (1986). Key surfaces are 


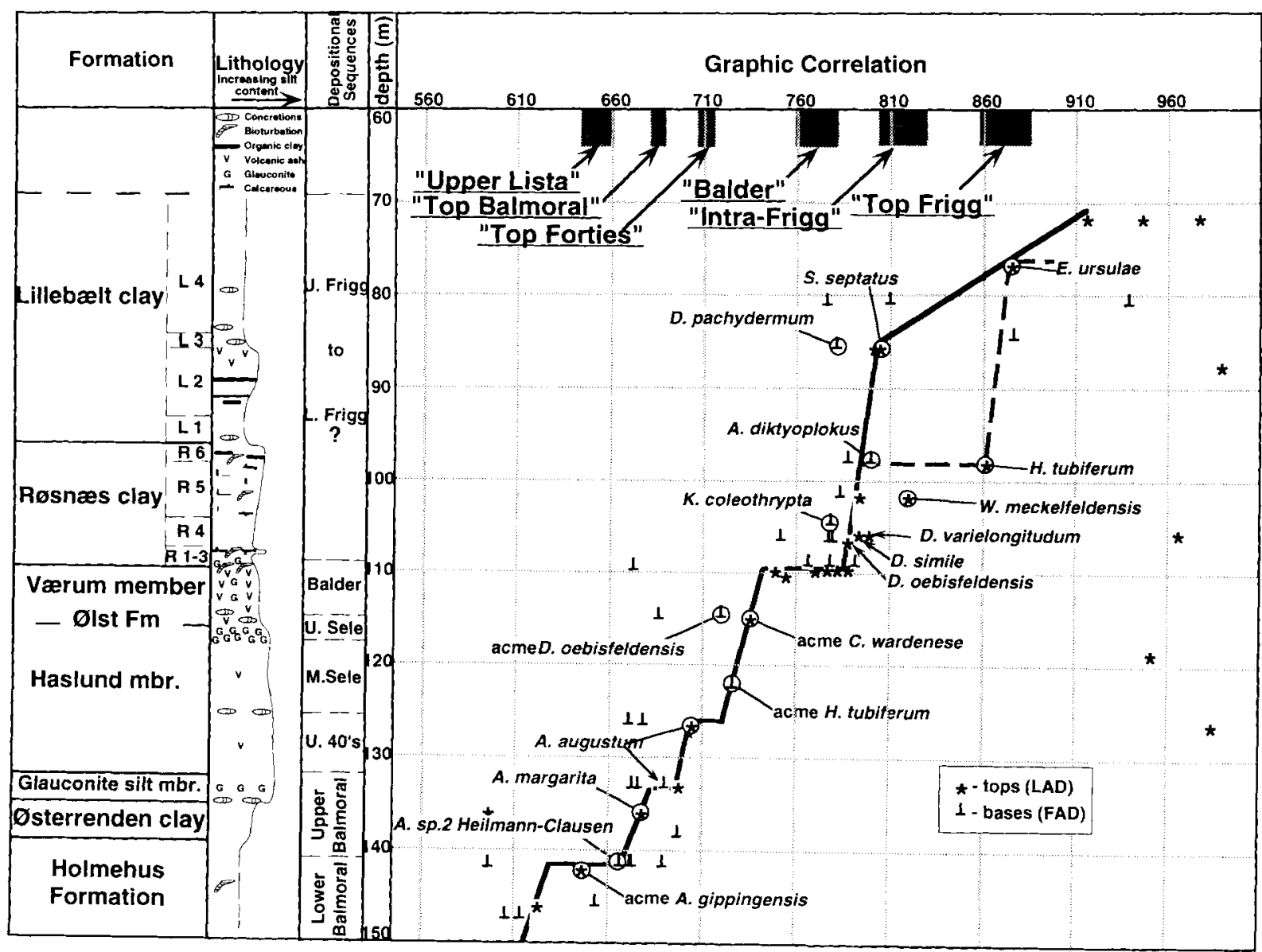

Fig. 14. Graphic correlation of the dinoflagellate stratigraphy from the D.G.I. 83101 borehole at $\emptyset$ sterrenden. Overlapping data terraces from the Central North Sea are plotted at the top for comparison. Lithology column and formations come from Nielsen et al. (1986), depositional sequences are named by their age-equivalent units in the Central North Sea (see text for further explanation).

difficult to locate in the section and are sometimes ambiguous with respect to sequence stratigraphic methodology. Glauconitic intervals described near the top of the Haslund member of the $\varnothing 1 \mathrm{st}$ Formation $(118 \mathrm{mbsl})$ and the informal Glauconite Silt member $(133-136 \mathrm{mbsl})$ are interpreted to represent very slow marine sedimentation and may represent maximum flooding events or highstand periods. The dinocyst Apectodinium augustum (Harland, 1979), appears just above the sharp top contact of the Glauconite Silt member and this FAD helps define a data terrace that overlaps with the Mid-Balmoral terrace in the basin. Likewise, the top of $A$. augustum marks another terrace that overlaps with the Top Forties Hiatal Interval in the basin. A reported concretion layer that may also represent sediment starvation occurs at this boundary.

The glauconitic horizon at $118 \mathrm{mbsl}$ in the $\emptyset$ sterrenden borehole likely represents a stratigraphic gap, but is unresolvable with graphic correlation. The occurrence of more abundant $C$. wardenense and $D$. oebisfeldensis above this layer suggests a correlation with the Upper Sele depositional sequence, which is also unresolvable in the North Sea with graphic correlation (see Fig. 11). The overlying Værum member with volcanic tuff layers correlates laterally to the Fur Formation (Heilmann-Clausen et al., 1985) and is widely accepted as the equivalent of the Balder Tuff in the North Sea (Knox \& Harland, 1979; Knox, 1984; Morton \& Knox, 1990). Graphic correlation confirms this tie as the $\emptyset_{\text {sterrenden borehole displays a major terrace }}$ at the Røsnæs Clay/Værum member boundary, which overlaps the Balder Hiatal Interval in time. Nielsen et al. (1986) recognize this contact as an unconformity with burrowing and as a condensed R1-R3 unit. Interpreting the remainder of the Røsnæs Clay Formation and the overlying Lillebælt alay is very difficult. The top of $H$. tubiferum occurs much lower than expected, and the introduction of other key markers such as bases for Areosphaeridium diktyoplokus (Klumpp, 1953) and Dracodinium pachydermum (Caro, 1973) and a low top of Kisselovia coleothrypta (Williams \& Downie, 1966) present correlation problems between the Central North Sea and Denmark. Two interpretations are presented. The terraced line honours the top of $H$. tubiferum, which is usually found in the basin near the top of $E$. ursulae, and places a large stratigraphic gap within unit R6. This interpretation places the Lillebælt Clay 
as age-equivalent to a large part of the Top Frigg Hiatal Interval, and is evidence for the partitioning of sediment to the outcrop sections during times of sediment starvation in the Central North Sea. The second interpretation ignores the top of $H$. tubiferum and considers it a 'depressed' top (see above), honouring instead the top of $S$. septatus and the base of $D$. pachydermum. This interpretation is more conservative, and is preferred after examining other boreholes that have $H$. tubiferum lower than predicted.

The deepest biostratigraphic boundary for this borehole occurs within the Holmehus Formation. A sequence boundary is picked solely on the biostratigraphy and equated with the Lower Balmoral/Upper Balmoral break in North Sea wells. This terrace corresponds to the upper part and boundary of dinoflagellate zone 4 in the Viborg borehole (Nielsen et al., 1986: 246), and is an example of an inferred correlation where little evidence for a stratigraphic break exists in the rocks. This correlation helps carry the stratigraphy as a tie for North Sea biostratigraphy to the outcrop sections. The importance of this type of correlation is illustrated by a graph for the Viborg borehole (Fig. 15).

\section{Viborg borehole}

The Viborg borehole (see Fig. 1 for location) encountered Palaeogene sediments from the Røsnæs Clay down to Danian Limestone (Heilmann-Clausen, 1985). This borehole is critical in tying a nannofossil stratigraphy of NW Europe to the graphic correlation stratigraphy of the Central North Sea. The nannofossil tie comes from a correlation of Viborg dinoflagellate zones within the stratigraphic framework of Michelsen et al. (in press), which tied nannofossil zones to the dinoflagellates indirectly through correlation with other European basins (Heilmann-Clausen, pers. comm.). Nannofossil zones are very difficult to identify with cutting samples since most standard NP zones are based on FADs (Martini, 1971), however, nannofossil stratigraphy is presently the most complete correlation framework in NW Europe (Aubry, 1986; Aubry et al., 1986).

Figure 15 displays how the North Sea terraces relate to nannofossil zones and the older deposits not encountered in the $\emptyset$ sterrenden borehole. A good correlation is achieved with the Balder, Top Forties, Mid-Balmoral, and Upper Lista Hiatal Intervals and the Viborg line of correlation.

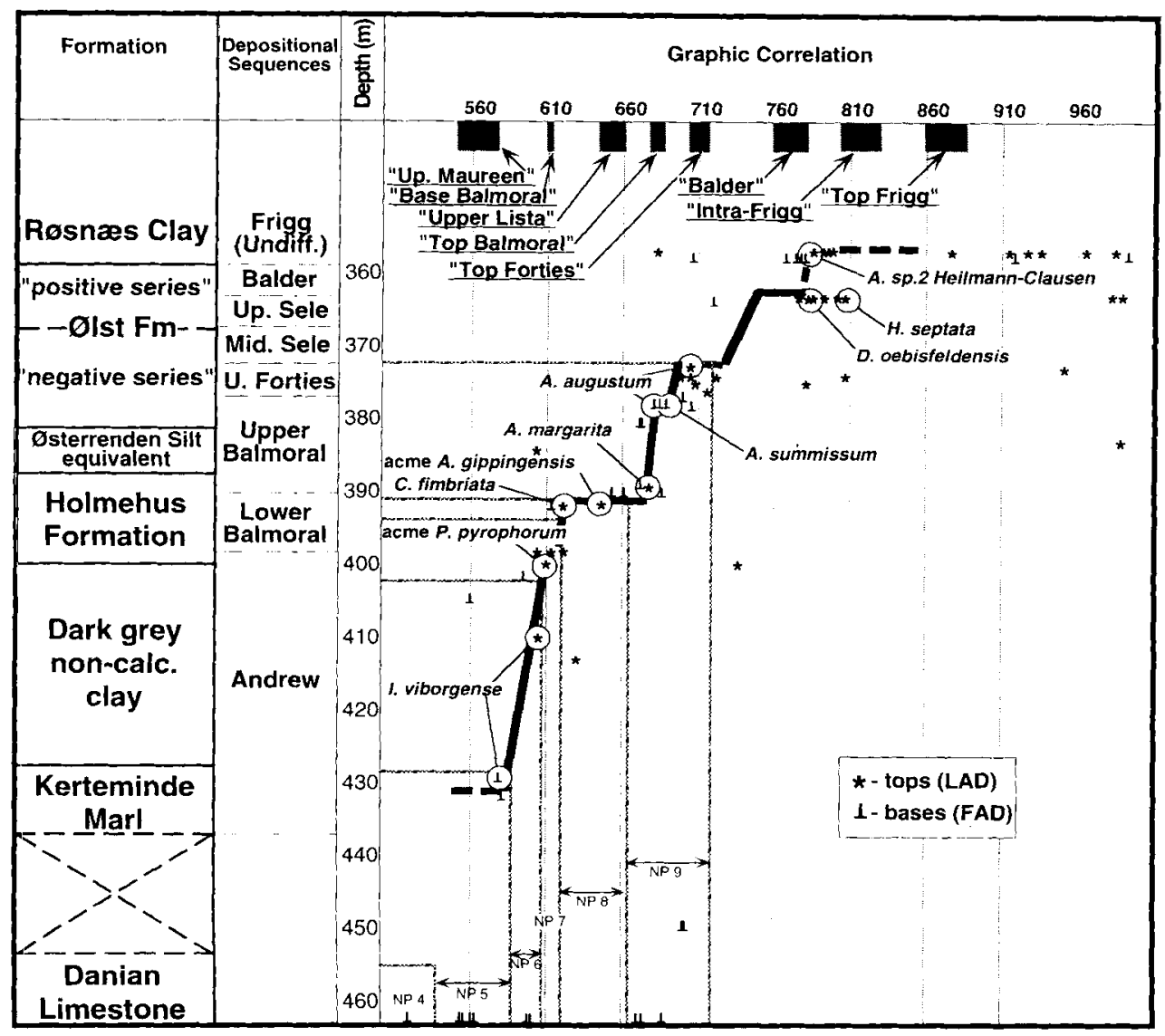

Fig. 15. Graphic correlation plot of dinoflagellate stratigraphy from the Viborg borehole (Heilmann-Clausen, 1985). Nannofossil correlations come from the stratigraphic framework of Michelsen et al. (in press), correlated to Viborg dinoflagellate zones. Overlapping data terraces from the Central North Sea are plotted at the top for comparison (see text for further discussion). 
Additionally, the Base Balmoral terrace is well developed at Viborg, correlating to a level near the base of the Holmehus Formation. It is possible that this terrace is 'artificially' long (see discussion above), however, as it occurs at the base of an $8 \mathrm{~m}$ thick barren interval. The Upper Maureen terrace probably correlates within the sample gap between the Kerteminde Marl and Danian Limestones. This presents an interesting correlation where Danian limestones are age-equivalent to clastic fan deposition of the Maureen sequence in the Central North Sea.

\section{Whitecliff Bay section}

The Eocene succession at Whitecliff Bay on the Isle of Wight (see location, Fig. 1) has been described in detail with calcareous nannofossil studies by Aubry (1983, 1986), dinoflagellate cyst stratigraphy by Eaton (1976), and the sedimentologic work of Plint (1983). The sequence stratigraphic study of these outcrops by Plint (1988), correlates to the eustatic curve of Haq et al. (1987), and achieves a good fit. To compare this work with our current study, the dinoflagellates of Eaton (1976) were graphed against the composite standard used in the North Sea and Denmark. The resulting plot and interpretation is shown in Fig. 16.

Sequence stratigraphic interpretation of this section is modified from Plint (1988), by correlating sequences described in other basins and using the original depositional environment descriptions of Plint (1983). Sequences at

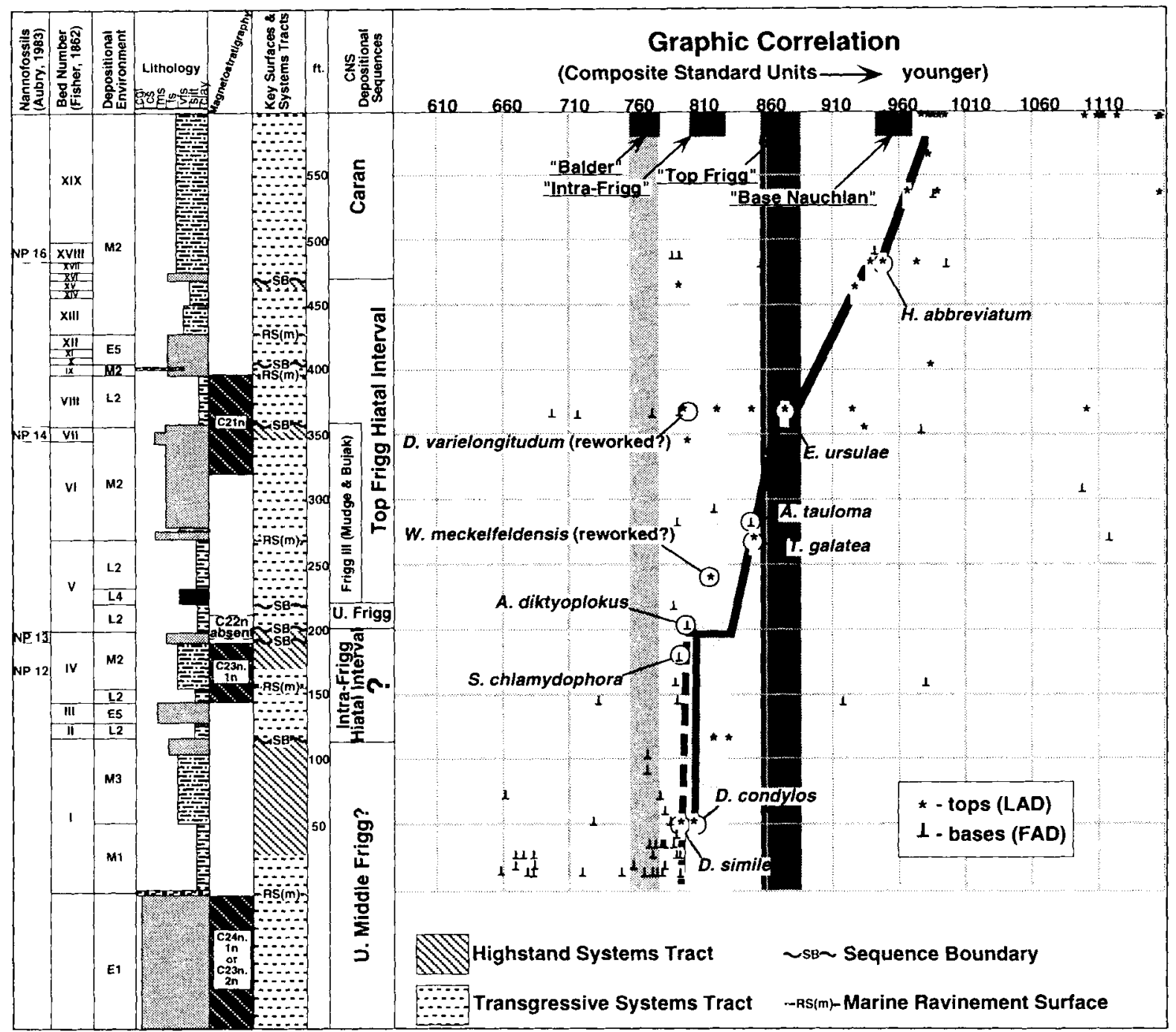

Fig. 16. Graphic correlation plot of the dinoflagellate stratigraphy from Eaton (1976) of the Bracklesham succession at Whitecliff Bay. Lithologies and depositional environmoents are modified from Plint (1983), as is the sequence stratigraphy (Plint, 1988). Nannofossil picks come from Aubry (1983, 1986). Magnetostratigraphy $(=$ normal polarity) comes from Aubry et al. (1986). Overlapping data terraces from the Central North Sea are plotted at the top, demonstrating the difficulty of correlation with the Central North Sea (see text for further explanation). 
Whitecliff are related to Central North Sea sequences by graphic correlation. Fisher Bed I is correlated to the upper part of the Middle Frigg sequence in the basin. The Middle Frigg sequence is split into two sequences onshore with the Portsmouth sand in London Clay Division D (King, 1981; Plint, 1988 - not shown in Fig. 16) being the lower part. Two possible interpretations are presented for Fisher Bed I. If the tops of Dracodinium condylos (Williams \& Downie, 1966) and Dracodinium simile (Eisenack, 1954) are honoured, a large amount of section falls within the Intra-Frigg Hiatal Interval when correlating to the basin. If the bases of Samlandia chlamydophora (Eisenack, 1954) and A. diktyoplokus are honoured, the correlation of this section to the basin requires an additional sequence. For consistency in correlation to the basin, we have chosen to honour the tops in this instance. Interpretation of the section from upper Fisher Bed IV through Bed V is very difficult. The position of a terrace at the base of Fisher (1862) Bed V is strongly influenced by the recognition of a biostratigraphic and magnetostratigraphic gap at that horizon (Aubry et al., 1986). This hiatus is correlated to a major eustatic fall at the top of the Ypresian, ' $49.5 \mathrm{Ma}$ ' on the Haq curve (Aubry, 1991; Plint, 1988; P.R. Vail, pers. comm.). Intuitively, the Lower Eocene Frigg regression in the North Sea should tie to this globally-recognized major sea-level fall, yet graphic correlation shows that this event is younger than the main Frigg sands (see Fig. 11). It is believed that the major short-term sea-level falls documented globally for this time (Aubry, 1991; Haq et al., 1988) are subdued in the North Sea due to long-term sea-level rise with deposits from this major fall appearing locally in the North Sea (Upper Frigg sequence). The bed at the top of Fisher IV has NP 13 fossils (Aubry, 1983) and the base Fisher V event correlates with the Upper Frigg Sequence or Frigg-III Sequence recognized by Mudge \& Bujak (1994). The base Fisher V sequence boundary may correlate to the deeply incisive sequence in the 23.1 zone of Den Hartog Jager et al. (1993), but is difficult to place within our subsurface framework. The high amplitude seismic reflector below the Top Frigg Hiatal Interval shows considerable erosional topography in the shelfal areas of UK Quadrants 14 and 15 that may be related to a fall in sea-level, however, the Upper Frigg Sequence is thin in most parts of the basin.

Sequence interpretations are made based on basinward shifts of facies, where shallow water sediments rest directly on deeper ones, indicating a sea-level fall. The Whitecliff section records many more such events than are resolved with graphic correlation. Some of these sequences correlate in time to hiatal intervals of sediment starvation in the North Sea (Fisher Beds I, XIX, II-IV?). This correlation suggests two points: (1) outcrop sections in Europe can correspond to data terraces in the North Sea biostratigraphy and probably are the highstand and transgressive systems tracts equivalents of high gamma shale drapes in the basin; (2) more sequences are described in outcrop than are documented in the basin. This second point emphasizes the importance of integrating both outcrop and subsurface data sets to build a complete sea level history for the North Sea and its connected NW European basins.

\section{Wursterheide borehole}

Recognition of sequences in deeper water sections without obvious facies shifts is accomplished with electric log data and grain size analysis. This information, combined with biostratigraphy, aids in the recognition of more subtle boundaries. These subtle boundaries are recognized in Ieper clay sections of Belgium (Vandenberghe et al., 1988). The Northern Germany section, represented in boreholes is similar in this respect. The Wursterheide borehole (Fig. 17 - see Fig. 1 for location) cored a thick lower Eocene silt/clay section with extensive dinoflagellate cyst recovery (Heilmann-Clausen \& Costa, 1989). The Lower Eocene section from $570 \mathrm{~m}$ to $720 \mathrm{~m}$ has one of the best defined LOCs in the basin. Most of this section would normally fall within the Balder hiatal interval in the Central North Sea (Fig. 17). Subtle increases and decreases in gamma ray value represent changes in silt and organic content interpreted as indications of sea level change. By correlating the biostratigraphy, these gamma ray trends are related to shallow water age-equivalent deposits where sea-level change is more noticeable. Sequence names come from correlative formations in the London-Hampshire and Belgium Basins. Correlation of the LOC for the labelled Lower and Middle Frigg sequences in the Wursterheide well compares favourably with the Frigg section in N25/1-3. Numerous Dracodinium species are observed in both localities, providing a direct tie. A minor terrace may be interpreted at approximately $615 \mathrm{~m}$ well depth between $D$. simile and $D$. solidum similar to one seen in well N25/1-3 (see Fig. 11), which corresponds to the maximum flooding surface of the Christchurch/Lower Frigg Sequence at Wursterheide. At $571 \mathrm{~m}$ well depth, however, a major data terrace develops that can be linked to a gamma ray marker. This terrace overlaps with the Intra-Frigg hiatal interval of the Central North Sea, but is also slightly older than the overlap interval observed from other wells. Ties to dinoflagellate zones places this gap in the upper part of zone D 8 (IGCP \#124 Subgroup - Vinken, 1988) since the top of $A$. summissum occurs with the base of $S$. chlamydophora, and the base of $A$. diktyoplokus is in the next sample. When correlated to the Belgium section, this gap covers two sequences, the Egem and Kortemark, as the base of $S$. chlamydophora occurs within the Kortemark and the base of A. diktyoplokus occurs in the Egem sands above (DeConinck, 1990). Here, a datum top occurs with these bases to provide a more secure correlation with the Central North Sea. If this hiatus is due to sediment starvation resulting from a deepening, then sediments above the hiatus may represent a lowstand depositional pulse similar to the Central North Sea. The coarsening upward gamma signal becomes a lowstand prograding wedge that correlates in outcrop to the Egem Stone Band/Merelbeke clay layer above the Egem sand. The Merelbeke clay is interpreted as very shallow deposits with fresh water influence (Steurbaut \& Nolf, 1986), and represents marginal marine transgressive deposits above the sequence boundary at the top of the Egem. The fining upward silt from 540 to $525 \mathrm{~m}$ in the Wursterheide well then becomes the transgressive systems tract, and the coarsening upward section from 525 to $503 \mathrm{~m}$ 


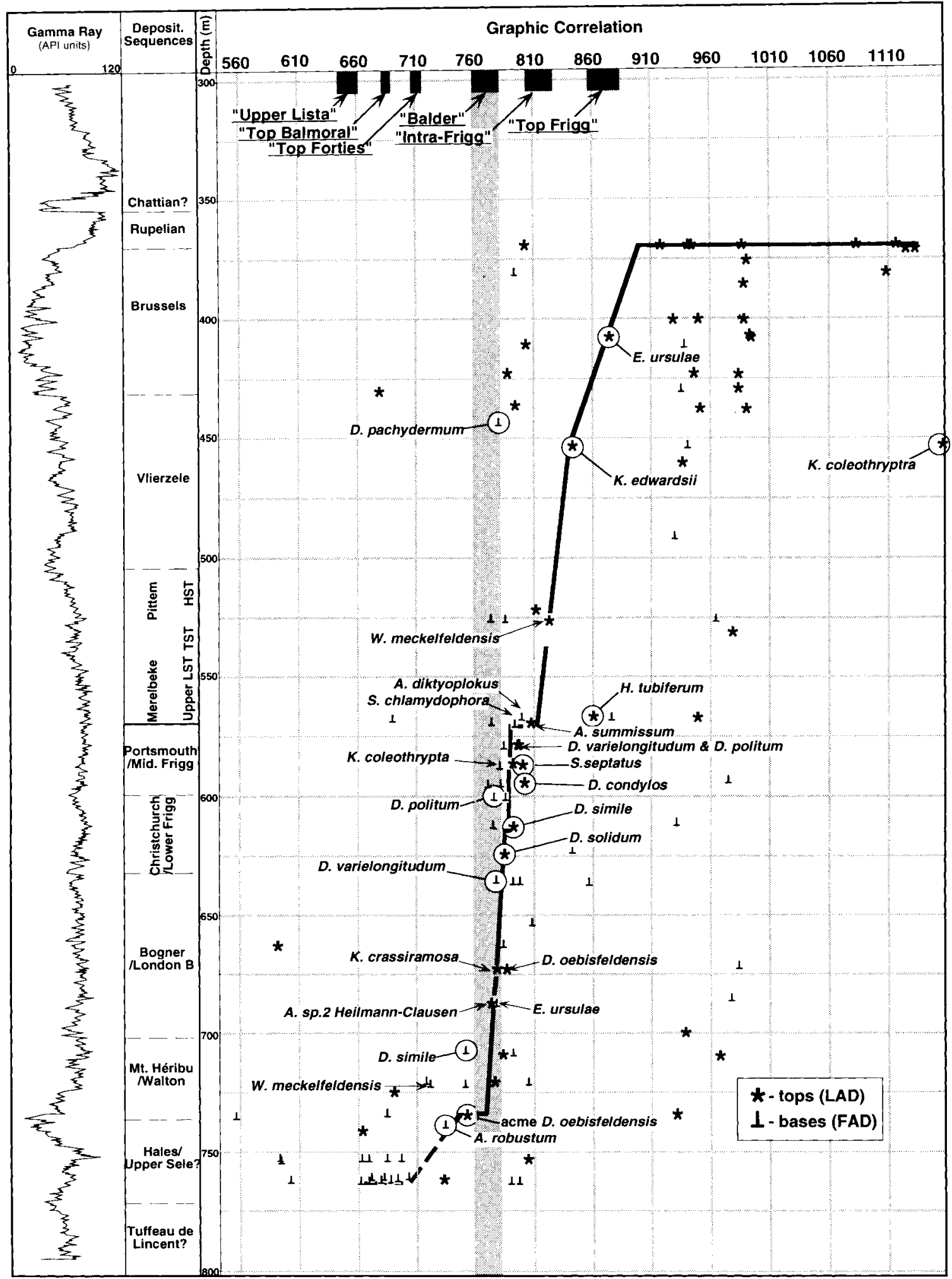

Fig. 17. Graphic correlation of dinoflagellates in the North German Wursterheide borehole from Heilmann-Clausen \& Costa (1989). In this section, the overlapping 'Balder' LOC offset from the North Sea corresponds to an interval of deposition. Interpretation of gamma ray log identifies depositional sequences that are observed elsewhere in Northwest Europe. 
is then the highstand systems tract (Pittem clay equivalent). The sharp change in the gamma log above $503 \mathrm{~m}$ consequently belongs to the Vlierzele sequence, which has also been related to the ' $49.5 \mathrm{Ma}$ ' sea level fall (De Baptist, 1989; P.R. Vail, pers. comm.) of Haq et al. (1987). The line of correlation for the section from 503 to around $430 \mathrm{~m}$ compares well with a similar line within the Upper Frigg Sequence of UK 8/27a-1 (Fig. 11).

\section{Chronostratigraphic summary section}

When information from as many sources as possible is integrated, a chronostratigraphic chart for all basins studied is built (Fig. 18). This correlation chart provides insight into palaeogeography of the time slice studied, relating basinal lowstand deposits to shelfal transgressive and highstand ones. Comparison of events documented in this study to those predicted by the Haq et al. (1988) curve demonstrates that a eustatic signal can be identified in Northwest Europe, but that additional cycles are required to fully describe the sections. The eustatic curve has been modified here by matching the nannofossil zones of Haq et al. (1988) to those of Aubry et al. (1988), correlated to the revised magneto-chronostratigraphy of Cande \& Kent (1992). Nannofossil zones are correlated to planktonic foraminifera zones (J. Hardenbol \& W.A. Berggren, pers. comm. 1994), which provide the true link of biostratigraphy to magnetostratigraphy, therefore these correlations should be regarded as tentative until a revised correlation of nannofossils to foraminifera is published for the new time scale.

Units that appear continuous in outcrop (e.g. London and Ieper Clay Formations) may actually contain bypass surfaces that are shown as missing section in Fig. 18. These intervals are necessary to place Central North Sea lowstand deposits into a chronostratigraphic framework with NW Europe outcrops. An alternate possibility is that outcrop sequence boundaries are Type 2 (Van Wagoner et al., 1988), with no lowstand, but the same sequence boundary is Type 1 in the North Sea due to enhancement by tectonics (Vail et al., 1991). This problem simply reemphasizes the dangers of separating sea level change magnitudes without considering the interaction of long- and short-term cyclic conditions.

\section{DISCUSSION}

The key to establishing a reproducible sequence stratigraphic framework is good age control (biostratigraphy, magnetostratigraphy, isotope stratigraphy, etc.). Recent publications highlight the complex problem of verifying the age-equivalence of key bounding surfaces (Hardenbol, 1992; Aubry, 1991), and the observation of depositional sequence-forming mechanisms at different time scales (Posamentier et al., 1992a). In Northwest Europe, construction of a surface-based stratigraphy is difficult because there are more key surfaces than biostratigraphic zones. The most recent biostratigraphic zonations are very high resolution and have greatly enhanced correlations (e.g. Jolly, 1993), however, biostratigraphic zones do not represent physical surfaces in the rocks and problems arise when correlating deep marine biostratigraphy to shallow sections. Certain key markers may be environmentallycontrolled or subject to reworking, which introduces another possibility of correlation error. Correlation by biozones based mainly on FADs, although the most common practice onshore, is often at odds with correlation by key markers (usually LADs or acme occurrences), the most common practice in the North Sea. Good examples of this problem are the placement of the top $H$. tubiferum marker, which falls within the Top Frigg Hiatal Interval in the basin but occurs in older rocks in outcrop, and the base of $D$. pachydermum, which is carried lower in the North Sea composite standard than its proper relative position in outcrop correlations.

These examples illustrate the need to combine basinal marker correlation and outcrop zonal correlation. Graphic correlation is a hybrid between the two systems and attempts to capture the best feature of each. It has the potential to isolate problems in the biostratigraphic data due to reworking or environmental factors while adding a chronological control that is beyond most zonal schemes. Overlapping data terraces is the best available way to establish chronological correlations, even though the interpretation of a line of correlation and its complexity may be non-unique. Graphic correlation is preferred over the condensed section approach in the North Sea basins where depositional rates are relatively low. The condensed section approach is most successful identifying intervals of slower than normal sedimentation in basins where general deposition rates are high. For example, in the Gulf of Mexico, condensed sections over $300 \mathrm{ft}$ thick have been published (see examples from Armentrout and Clements, 1991 -Figs $3 \& 4$ ). These sections should be referred to as 'relatively condensed' if the sedimentation rate exceeds the $<1 \mathrm{~cm} / \mathrm{ka}$ proposed by Loutit et al. (1988). The Central North Sea Palaeogene section has a punctuated sedimentation history with slower depositional rates. Correlation within the Central North Sea Palaeogene requires a different biostratigraphic approach than the methods used in the Gulf of Mexico. Using a chronostratigraphic framework of terrace-bounded units, this study produces a sequence stratigraphy for northern European basins, based on correlation of key bounding surfaces, recognizing nested cycles and providing insight into palaeogeographic changes from shelf to basin.

\section{CONCLUSIONS}

By integrating seismic, well log, outcrop, and biostratigraphic data, we show how a sequence stratigraphic model may be built for a basin once a solid chronostratigraphic framework is in place using the graphic correlation method. Our conclusions on the stratigraphy of the Palaeogene for the North Sea and NW Europe are that sedimentation in the Central North Sea occurs as a series of punctuated depositional pulses separated by time-correlative biostratigraphic data terraces, referred to as hiatal intervals. However, not all sequence boundaries that are observable in the physical stratigraphy are resolvable by graphic correlation, but the method serves to bracket packages that are defined in outcrop, by seismic, or by well $\log$ 


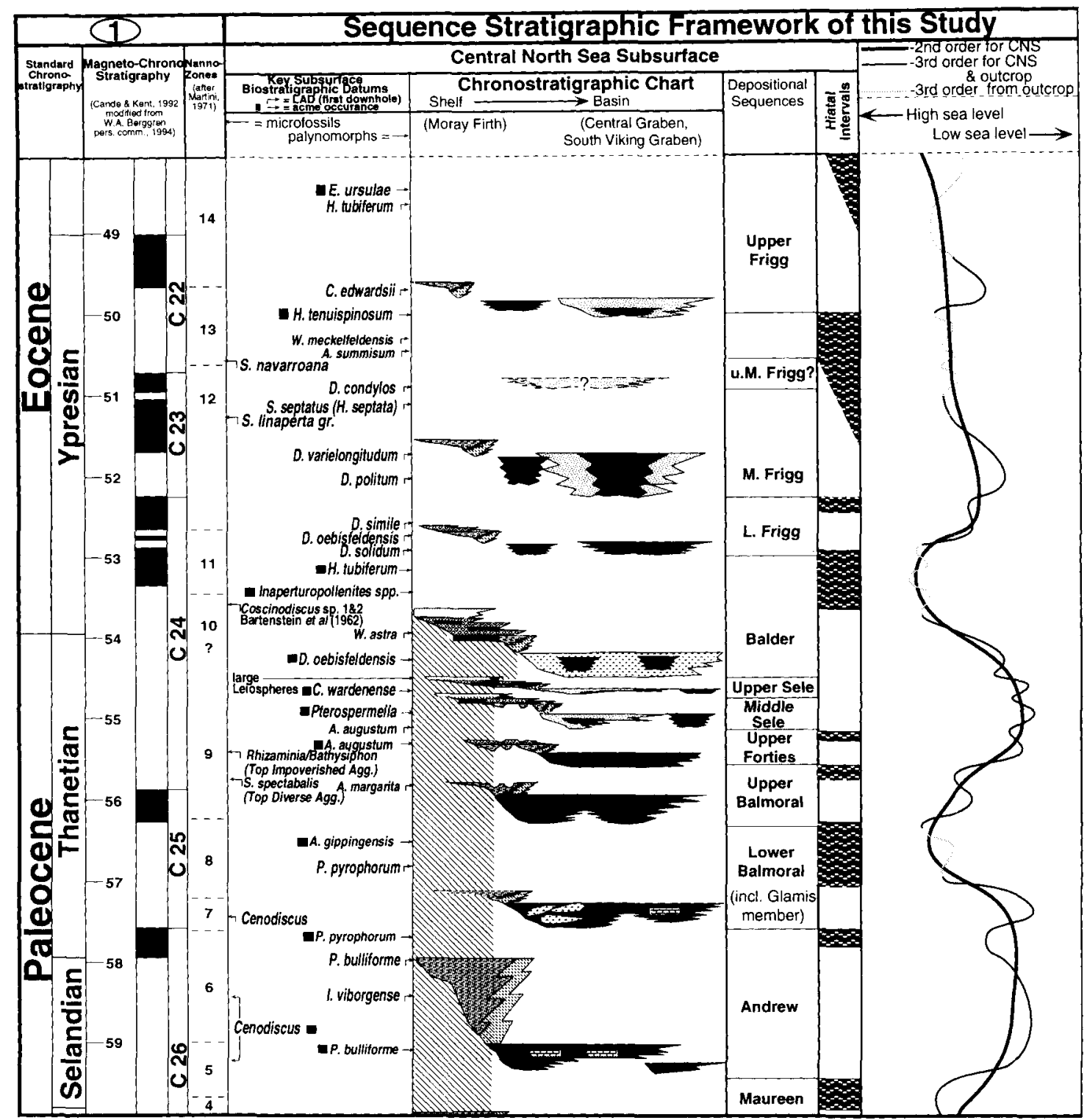

Fig. 18. Chronostratigraphic chart for Northwest Europe for deposits of Selandian to Lutetian age. Palacogeographically, lowstand deposits in the Central North Sea correspond to sequence boundaries in outcrop sections and marine hiatal intervals in the basin tie to multi-sequence outcrop sections.

* Missing section may be caused by wave base erosion or subaerial exposure during sea-level fall, or tectonic uplift (especially in the Thanetian section of the Central North Sea). (1) = revised time scale from Cande \& Kent (1992), with nannofossil corelations from Aubry et al. (1988). ${ }^{2}$ Outcrop correlations arc compiled primarily from the work of Heilmann-Clausen (1985), Thomsen \& Heilmann-Clausen (1985), Nielsen et al. (1986), Heilmann-Clausen \& Costa (1989), Michelsen et al (in press), Vandenberghe et al. (in press \& 1988), De Coninck (1990), Steurbaut, (1988), Plint (1983, 1988), Knox et al. (in press), Ali et al. (1993), Eaton (1976), J. Riveline (pers. comm.), Cavalier (1987), Cavalier \& Pomerol (1986), Berggren \& Aubry (1993), Aubry (1986, 1983) and Gély \& Lorenz (1991). «New (O \& SS) = position of a sequence boundary from outcrop and subsurface data not picked in Haq et al. (1988) $\leftarrow$ New (O) = position of a sequence boundary from outcrop data not picked in Haq et al. (1988). The Haq et al. (1988) eustatic curve is modified based on a correlation of nannofossil zone differences between Haq et al. (1988) and Aubry et al. (1988)

Lithology and Facies key

Hemipelagic Mud/Marine Hiatus $\square$ Lowstand Progradfing $\frac{1}{\text { sandlshalc }}$ Tuff

Dominantly-Silt Turbidites \% Transgressive Surfaces $----\mathrm{Coal}$

Dominantly-Sand Turbidites Transgressive Shoreface/Estuary Sands

Graphic Correlation Data Terrace Erosion or Missing Section $\mathrm{NST}$

Highstand SiltSand 5 Sequence Boundary (SB)

Estuarine/Lagoon Shales

Nonmarine Sand/Shale $[x$ Glauconite $x-\rightarrow$ Incisive SB 


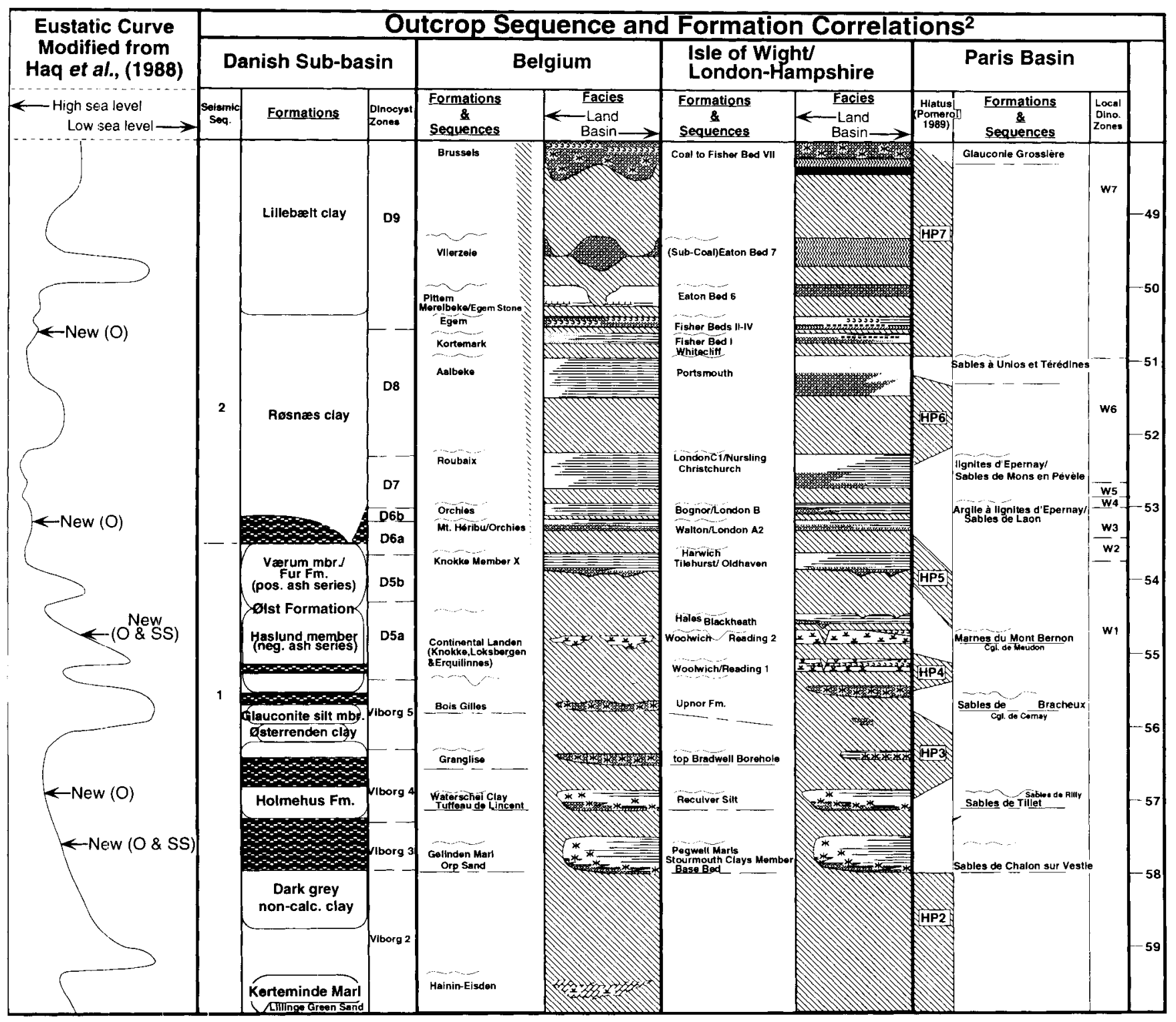

interpretation. When sequence stratigraphic interpretations of outcrop and borehole sections from NW Europe are incorporated into the chronostratigraphic framework of the Central North Sea, a genetic link between the shallow and deep sections is proposed, which assists in the development of a palaeogeographic and geologic depositional model for the study area.

\section{ACKNOWLEDGMENTS}

The authors wish to thank Amoco Production Co. for permission to publish this paper. J.N.'s research was funded by Amoco in Houston and London and thanks are due $\mathrm{A}$. Berman for arrranging funding in Houston and Paris. Thanks are due as well to GECO-Prakla, Nopec, and SPT (Horizon Geophysical and Robertson Research) for permission to display their data. J.N. thanks P.Ch. de Graciansky for research support at the Ecole des Mines in
Paris. Discussions with numerous scientists working on the Tertiary correlations in Northwest Europe provided invaluable insight to this project, especially J. Hardenbol, N. Vandenberghe, C. Heilmann-Clausen, H. Jordt, R.W.O.'B. Knox, C. King, J. Riveline, N. Milton, P. Copestake, S. O'Connor, T. Berg, and D. White, with the hiatal interval concept developing from discussion with M.P. Aubry and J. Sneider. Review by K. Coterill, A. Droxler, R. Harland and R.W.O.'B. Knox greatly improved this manuscript. Special thanks go to P.R. Vail for this advice and guidance of this research and the Mesozoic-Cenozoic Sequence Stratigraphy of European Basins Project.

\section{REFERENCES}

Ali, J. R., King, C. \& Hailwood, E. A. 1993, Magnetostratigraphic calibration of the Early Eocene depositional sequences in the southern North Sea Basin. In Hailwood, E. A. \& Kidd, R. B. 
(Eds) High Resolution Stratigraphy. Geological Society, London, Special Publication, 70: 99-125.

Armentrout, J. M. 1991. Paleontologic constraints on depositional modeling: examples of integration of biostratigraphy and seismic stratigraphy, Plio-Plicstocene, Gulf of Mexico. In Weimer, P. \& Link, M. (Eds), Seismic Facies and Sedimentary Processes of Submarine Fans and Turbidite Systems, Frontiers in Sedimentary Gcology Series, 137-170, Springer-Verlag, New York.

Armentrout, J. M. \& Clements, J. F. 1991. Biostratigraphic calibration of depositional cycles: A case study in High Island-Galveston-East Breaks areas, offshore Texas. In Armentrout, J. M. \& Perkins, B. F. (Eds), Sequence Stratigraphy as an Exploration Tool, Concepts and Practices in the Gulf Coast, Eleventh Annual SEPM Research Conference, Gulf Coast Section, 21-51, Earth Enterprises, Inc., Austin.

Armentrout, J. M., Echols, R. C. \& Lee, T. D. 1991. Patterns of Foraminiferal abundance and diversity: Implications for sequence stratigraphic analysis. In Armentrout, J. M. \& Perkins, B. F. (Eds), Sequence Stratigraphy as an Exploration Tool, Concepts and Practices in the Gulf Coast, Eleventh Annual SEPM Research Conference, Gulf Coast Section, 53-58, Earth Enterprises, Inc., Austin.

Armentrout, J. M., Malacek, S. J., Fearn, L. B., Sheppard, C. E., Naylor, P. H., Miles, A. W., Desmarais, R. J. \& Dunay, R. E. 1993. Log-motif analysis of Paleogene depositional systems tracts, Central and Northern North Sea: defined by sequence stratigraphic analysis. In Parker, J. R. (Ed.), Petroleum Geology of Northwest Europe: Proceedings of the 4th Conference, 45-58, Geological Society, London.

Aubry, M.-P. 1983. Biostratigraphie du Paléogène epicontinental de r Europe du Nord-Ouest. Etude fondée sur les nannofosiles calcaires. Doc. Lab., Geol. Lyon, 89.

Aubry, M.-P. 1986. Paleogene calcareous nannoplankton biostratigraphy of Northwestern Europe. Palaeogeography, Palaeoclimatology, Palaeoecology, 55: 267-334.

Aubry, M.-P. 1991. Sequence Stratigraphy: Eustasy or Tectonic Imprint? Journal of Geophysical Research, 96(B4): 6641-6679.

Aubry, M.-P., Berggren, W. A., Kent, D. V., Flynn, J. J., Klitgord, K. D., Obradovich, J. D. \& Prothero, D. R. 1988. Paleogene geochronology: an integrated approach. Paleoceanography, $3(6)$ : 707-742.

Aubry, M.-P., Hailwood, E. A. \& Townsend, H. A. 1986. Magnctic and calcareous-nannofossil stratigraphy of the Lower Palaeogene formations of the Hampshire and London-basins. Journal of the Geological Society, London, 143: 729-35.

Berggren, W. A. \& Aubry, M.-P. 1993. A late Paleocene-carly Eocene NW European and North Sea magneto-biostratigraphic correlation network: a sequence stratigraphic approach (abs.) In Knox, R. W. O'B., Corfield, R. \& Dunay, R. E. (convenors), Correlation of the Early Paleogene in Northwest Europe, Programme and Abstracts from 1-2 December meeting at the Geological Society of London sponsored by the Stratigraphic Committee and The Petroleum Group.

Bertram, G. T. \& Milton, N. J. 1988. Reconstructing basin evolution from sedimentary thickness; the importance of paleobathymetric control, with reference to the North Sea. Basin Research, 1: 247-257.

Cande, S. C. \& Kent, D. V., 1992. A new geomagnetic polarity time scale for the late Cretaceous and Cenozoic. Journal of Geophysical Research, 97(B10): 13,917-13,951.

Cavalier, C. 1987. Diachronisme des faciès et discontinuités dans la Paléogène. Bulletin d'Information des geologues du Bassin de Paris, Mémoir 6: 241-270.

Cavalier, C. \& Pomerol, C. 1986. Stratigraphy of the Paleogene. Bulletin de la Societe geologique de France, 8(2): 255-265.

Cross, T. A. 1988 . Controls on coal distribution in transgressiveregressive cycles, Upper Cretaceous, Western Interior, U.S.A. In Wilgus, C. K., Hastings, B. S., Kendall, G. C. St. C., Posamentier, H. W., Ross, C. A. \& Van Wagoner, J. C. (Eds), Sea-level changes: An Integrated Approach, 371-380, SEPM, Tulsa, Special Publication 42.

De Baptist, M. 1989. Seismistratigrafie en struktuur van het
Paleogeen in de Zuidelijke Noordzee. Doctoraatsthesis, R. U. Gent.

De Coninck, J. 1990. Ypresian organic-walled phytoplankton in the Belgian Basin and adjacent areas. Bulletin de la Société belge de Géologie, 97-3/4 (1988): 287-319.

Deegan, C. E. \& Scull, B. J. 1977. A Standard Lithostratigraphic Nomenclature for the Central and Northern North Sea. Institute of Gcological Sciences Report No. 77/25.

Den Hartog Jager, D., Giles, M. R. \& Griffiths, G. R. 1993. Evolution of Palcogene submarine fans of the North Sea in space and time. In Parker, J. R. (Ed.), Petroleum Geology of Northwest Europe: Proceedings of the 4th Conference, 59-72 Gcological Socicty, London.

Duval, B., Cramez, C. \& Vail, P. 1992. Types and hierarchy of stratigraphic cycles (abs.): Abstract volume from the Sequence Stratigraphy of European Basins Meeting in Dijon, France, May 18-20, 1992. CNRS-IFP.

Eaton, G. 1976. Dinoflagellate cysts from the Bracklesham Beds (Eocene) of the Isle of Wight, Southern England. Bulletin of the British Museum (Natural History) Geology Series, 26: 225-332.

Fisher, O., 1862. On the Bracklesham Beds of the Isle of Wight Basin. Quaterly Jounral of the Geological Society of London, 18: $65-93$.

Galloway, W. E. 1989. Genetic stratigraphic sequences in basin analysis II: Application to northwest Gulf of Mexico Cenozoic Basin. American Association of Petroleum Geologists Bulletin. 73: $143-154$.

Galloway, W. E., Garber, J. L., Xijin, Liu \& Sloan, B. J. 1993. Sequence stratigraphic and depositional framework of the Cenozoic fill, central and northern North Sea Basin. In Parker, J. R. (Ed.), Petroleum Geology of Northwest Europe: Proceedings of the 4th Conference, 33-44, Geological Society, London.

Gély, J.-P. \& Lorenz, C. 1991. Analyse séquentielle de l'Éocène et de l'Oligocène du bassin Parisien (France). Revue de l'Institut Français du Pétrole, 46(6): 713-747.

Gradstein, F. M., Kristiansen, 1. L., Loemo, L. \& Kaminski, M. A. 1992. Cenozoic foraminiferal and dinoflagellate cyst biostratigraphy of the central North Sea. Micropaleontology, 38(2): $101-137$.

Haq, B. U., Hardenbol, J. \& Vail, P. R. 1987. Chronology of fluctuating sea levels since the Triassic. Science, 235: 11561167.

Haq, B. U., Hardenbol, J. \& Vail, P. R. 1988. Mesozoic and Cenozoic chronostratigraphy and cycles of relative sea level change. In Wilgus, C. K., Hastings, B. S., Kendall, G. C. St. C., Posamentier, H. W., Ross, C. A. \& Van Wagoner, J. C. (Eds), Sea-level changes: An Integrated Approach. SEPM, Tulsa, Special Publication 42: $71-108$.

Hardenbol, J. 1992. Upper Paleocene to Lower Eocene Sequence Stratigraphic Framework of the U.S. Gulf Coast and Northwest Europe, (abs.): Abstract volume of the 26th Annual SouthCentral Section Meeting of the Geological Society of America, 24: February 24-25, 1992.

Harding, A. W., Humphrey, T. J., Latham, A., Lundsford, M. K. \& Strider, M. H. 1990. Controls on Eocene Submarine Fan Deposition in the Witch Ground Graben. In Hardman, R. F. P. \& Brooks, J. (Eds), Tectonic Events Responsible for Britain's Oil and Gas Reserves. Geological Society, London, Special Publication, 55: 353-367.

Harland, W. B., Armstrong, R. L., Cox, A. V., Craig, L. E., Smith A. G. \& Smith, D. G. 1990. A Geologic Time Scale 1989 , Cambridge University Press, Cambridge.

Heilmann-Clausen, C. 1985. Dinoflagellate stratigraphy of the Uppermost Danian to Ypresian in the Viborg 1 borehole, Central Jylland, Denmark. Danmarks Geologiske Undersogelse, Serte A, 7.

Heilmann-Clausen, C. \& Costa, L. 1989. Dinoflagellate zonation of the Uppermost Paleocene? to Lower Miocene in the Wursterheide Research Well, NW Germany. Geologisches Jahrbuch, A111: 431-521.

Heilmann-Clausen, C., Nielsen, O. \& Gersner, F. 1985. Lithostratigraphy and depositional environments in the Upper 
Paleocene and Eocene of Denmark. Bulletin of the Geologsical Soceity of Denmark, 33: 287-323.

Heritier, F. E., Lossel, P. \& Wathe, E. 1980. Frigg Field: Large submarine-fan trap in Lower Eocene rocks of the Viking Graben, North Sea. In Halibouty, M. (Ed.), Giant Oil and Gas Fields of the Decade 1968-1978. AAPG, Tulsa, Memoir 30: 59-80.

Isaksen, D. \& Tonstad, K. 1989. A revised Cretaceous and Tertiary lithostratigraphic nomenclature for the Norwegian North Sea. NPD-Bulletir No. 5.

Jolly, D. W. 1993. Provisional results of palynological investigations into the stratigraphy and palaeoecology of the Late Paleocene Lambeth Group. In Knox, R. W. O'B., Corfield, R., \& Dunay, R. E. (convenors), Correlation of the Early Paleogene in Northwest Europe, Programme and Abstracts from 1-2 December meeting at the Geological Society of London sponsored by the Stratigraphic Committee and The Petroleum Group.

Jones, R. W. \& Milton, N. J. 1994. Sequence Development During Uplift: The Palaeogene Stratigraphy and Relative Sea Level History of the Outer Moray Firth, UK North Sea. Marine and Petroleum Geology.

King, C. 1981. The stratigraphy of the London Clay and associated deposits. Tertiary Research Special Paper, 6.

Knox, R. W. O'B. 1984. Nannoplankton zonation and the Palaeocene/Eocene boundary beds of NW Europe: an indirect correlation by means of volcanic ash layers. Journal of the Geological Society, London, 141: 993-999.

Knox, R. W. O'B. \& Harland, R. 1979. Stratigraphic relationships of the early Palaeogene ash-series of NW Europe. Journal of the Geological Society, London, 136: 463-479.

Knox, R. W. O'B., Hine, N. \& Ali, J. in press. New information on the age and sequence stratigraphy of the type Thanetian of Southeast England. Newsletter on Stratigraphy.

Knox, R. W. O’B. \& Holloway, S. 1992. 1. Paleogene of the Central and Northern North Sea. In Knox, R. W. O’B. \& Cordey, W. G. (Eds), Lithostratigraphic nomenclature of the UK North Sea. British Geological Survey, Nottingham.

Kolla, V. \& Macurda, D. B. 1988. Sea-level changes and timing of turbidity-current events in deep-sea fan systems. In Wilgus, C. K., Hastings, B. S., Kendall, G. C. St. C., Posamentier, H. W., Ross, C. A. \& Van Wagoner, J. C. (Eds), Sea-level changes: An Integrated Approach. SEPM, Tulsa, Special Publication 42: $381-392$.

Loutit, T. S., Hardenbol, J., Vail, P. R. \& Baum, G. R. 1988. Condensed sections: The key to age determinations and correlation of continental margin sequences. In Wilgus, C. K., Hastings, B. S., Kendall, G. C. St. C., Posamentier, H. W., Ross, C. A. \& Van Wagoner, J. C. (Eds), Sea-level changes: An Integrated Approach. SEPM, Tulsa, Special Publication 42: 183-213.

Martini, E. 1971. Standard Tertiary and Quaternary calcareous nannoplankton zonation. In Farinacci, A. (Ed.), Proceedings of the Second Conference on Planktonic Microfossils, Rome, 1970, Rome, Tecnoscienza, 2: 739-785.

Michelsen, O., Danielsen, M., Heilmann-Clausen, C., Jordt, H., Laursen, G. \& Thomsen, E. in press. Occurrence of major sequence stratigraphic boundarics in relation to basin development in the Cenozoic deposits of the southeastern North Sea Sequence Stratigraphy of the North West Europe, NPD, Stavanger.

Miller, F. X. 1977. The graphic correlation method in biostratigraphy. In Kauffman, E. G. \& Hazel, J. E. (Eds), Concepts and Methods in Biostratigraphy, 165-186, Stroudsburg, P.A., Dowden, Hutchinson and Ross.

Milton, N. J., Bertram, G. T. \& Vann, I. R. 1990. Early Palaeogene tectonics and sedimentation in the Central North Sea. In Hardman, R. F. P. \& Brooks, J. (Eds), Tectonic Events Responsible for Britain's Oil and Gas Reserves. Geological Society, London, Special Publication No. 55: 339-351.

Mitchum, R. M., Jr., Vail, P. R. \& Thompson, S. III 1977. Seismic stratigraphy and global changes of sea level, part 2, the depositional sequence as a basic unit for stratigraphic analysis. $\ln$ Payton, C. E. (Ed.), Seismic Stratigraphy-applications to hydrocarbon exploration. AAPG, Tulsa, Special Publication, 26: 53-62.

Mitchum, R. M., Jr. \& Van Wagoner, J. C. 1991. High-frequency sequences and their stacking patterns: sequence stratigraphic evidence of high-frequency eustatic cycles. Sedimentary Geology, 70: $131-160$.

Morton, A. C., Hallsworth, C. R. \& Wilkinson, G. C. 1993. Stratigraphic evolution of sand provenance during Paleocene deposition in the North Sea area. In Parker, J. R. (Ed.), Petroleum Geology of Northwest Europe: Proceedings of the 4th Conference, 73-84 Geological Society, London.

Morton, A. C. \& Knox, R. W. O'B. 1990. Geochemistry of late Palaeocene and early Eocene tephras from the North Sea Basin. Journal of the Geological Society, London, 147: 425-437.

Mudge, D. \& Bujak, J. 1994. Eocene stratigraphy of the North Sea Basin. Marine and Petroleum Geology, 11: 166-181.

Mudge, D. \& Copestake, P. 1992. Revised Lower Palaeogene lithostratigraphy for the Outer Moray Firth, North Sea. Marine and Petroleum Geology, 9: 53-69.

Newton, S. K. \& Flanagan, K. P. 1993. The Alba Field: evolution of a depositional model. In Parker, J. R. (Ed.), Petroleum Geology of Northwest Europe: Proceedings of the 4th Conference, 161-173, Geological Society, London.

Nielsen, O., Baumann, J., Deyu, Z. \& Heilmann-Clausen, C. 1986. Tertiary deposits in the Store Balt. The Tertiary section of borehole D.G.I. 83101, Østerrenden, Store Bælt, Denmark. Geoskrifter, 24: 235-253.

O'Connor, S. J. \& Walker, D. 1993. Paleocene reservoirs of the Everest Trend. In Parker, J. R. (Ed.), Petroleum Geology of Northwest Europe: Proceedings of the 4th Conference, 145-160, Geological Society, London.

Parker, J. R. 1975. Lower Tertiary sand development in the Central North Sea. In Woodland, A. W. (Ed.), Petroleum Geology and the Continental Shelf of North West Europe, 447-453, Applied Science, Barking.

Parker, J. R. (Ed.). 1993. Petroleum Geology of Northwest Europe: Proceedings of the 4th Conference. Geological Society, London.

Plint, A. G. 1983. Facies, environments and sedimentary cycles in the Middle Eocene, Bracklesham Formation of the Hampshire Basin: evidence for global sea-level change? Sedimentology, 30: 625-653.

Plint, A. G. 1988. Global custasy and the Eocene sequence in the Hampshire Basin, England. Basin Research, 1: 11-22.

Pomerol, C. 1989. Stratigraphy of the Palaeogene: hiatuses and transitions. Proceedings of the Geologists' Association, 100: 313-324.

Posamentier, H. W., Allen, G. \& James, D. P. 1992. High-resolution sequence stratigraphy - the East Coulee delta. Journal of Sedimentary Petrology, 62: 310-317.

Posamentier, H. W., Erskine, R. D. \& Mitchum, R. M., Jr. 1991. Models for Submarine-Fan Deposition within a SequenceStratigraphic Framework. In Weimer, P. \& Link, M. (Eds), Seismic Facies and Sedimentary Processes of Submarine Fans and Turbidite Systems, 127-136, Springer-Verlag, New York, Frontiers in Sedimentary Geology Series.

Posamentier, H. W. \& Vail, P. R. 1988. Eustatic controls on clastic deposition II - Sequence and systems tract models. In Wilgus, C. K., Hastings, B. S., Kendall, G. C. St. C., Posamentier, H. W. Ross, C. A. \& Van Wagoner, J. C. (Eds), Sea-level changes: An Integrated Approach. SEPM, Tulsa, Special Publication 42: 125-154.

Powell, A. J. 1988. A modified dinoflagellate cyst biozonation for the latest Paleocene and earliest Eocene sediments from the North Sca. Review of Palaeobotany and Palynology, 56: 327-344.

Rochow, K. A. 1981. Seismic Stratigraphy of the North Sea 'Palaeocene' Deposits. In Illing, L. V. \& Hobson, G. D. (Eds), Petroleum Geology of the Continental Shelf of North-West Europe, 255-266, Heyden, London.

Sarg, J. F \& Skjold, L. J. 1982. Stratigraphic Traps in Paleocene Sands in the Balder Area, North Sea. In Halbouty, M. T. (Ed.), The Deliberate Search for the Stratigraphic Trap. AAPG Memoir 32: $197-206$. 
Shaw, A. B. 1964. Time in Stratigraphy, McGraw-Hill, Ncw York. Stein, J. A., Gamber, J. H., Krebs, W. N. \& La Coe, M. in press. A Composite Standard Approach to Biostratigraphic Evaluation of the North Sea Paleogene. Stratigraphy of North West Europe. NPD, Stavanger.

Steurbaut, E. 1988. New Early and Middle Eocene calcareousnannoplankton events and correlations in the middle to high latitudes of the northern hemisphere. Newsletters on Stratigraphy, 18(2): 99-115.

Steurbaut, E. \& Nolf, D. 1986. Revision of Ypresian Stratigraphy of Belgium and Northwestern France. Mededalingen van de Werkgroep voor Tertiaire en Kwaratare Geologie, 23(4): 115-172.

Stewart, I. J. 1987. A revised stratigraphic interpretation of the early Palaeogene of the central North Sea. In Brooks, J. \& Glennie, K. (Eds), Petroleum Geology of North West Europe, 557-576, Graham \& Trotman, London.

Thomsen, E. \& Heilmann-Clausen, C. 1985. The Danian-Selandian boundary at Svejstrup with remarks on the biostratigraphy of the boundary in western Denmark. Bulletin of the geological Society of Denmark, 33: 341-362.

Timbrell, G. 1993. Sandstone architecture of the Balder Formation depositional system, UK Quadrant 9 and adjacent areas. In Parker, J. R. (Ed.), Petroleum Geology of Northwest Europe: Proceedings of the 4th Conference, 107-122, Geological Society, London.

Vail, P. R. 1987. Seismic stratigraphy interpretation using sequence stratigraphy. Part I: Seismic stratigraphy interpretation procedure. In Bally, A. W. (Ed.), Atlas of Seismic Stratigraphy, American Association of Petroleum Geologists Studies in Geology 27(1): 1-10.

Vail, P. R., Audemard, F., Bowman, S., Eisner, P. \& Perez-Cruz, G. 1991. The stratigraphic signatures of tectonics, eustasy, and sedimentation. In Seilacher, D. \& Eisner, G. (Eds), Cycles and Events in Stratigraphy, 617-659, Springer-Verlag, Berlin.

Vail, P. R., Todd, R. G. \& Sangree, J. B. 1977. Seismic Stratigraphy and Global Changes of Sea Level, Part 5, Chronostratigraphic
Significance of Seismic Reflectors. In Payton, C.E. (Ed.), Seismic Stratigraphy - applications to hydrocarbon exploration. AAPG, Tulsa, Special Publication, 26: 99-116.

Vail, P. R. \& Wornardt, W. W. 1990. Well log seismic sequence stratigraphy: An exploration tool for the 90's. Eleventh Annual Research Conference, Gulf Coast Section, SEPM, Program and Abstracts, December 2-5, Earth Enterprises, Inc., Austin.

Vandenberghe, N., Laga, P., Steurbaut, E., Hardenbol, J. \& Vail, P. $R$. in press. Sequence stratigraphy of the Tertiary at the southern border of the North Sea Basin in Belgium. In Hardenbol, J., Vail, P., deGraciansky, P. C. \& Jacquin, T. (Eds.), Sequence Stratigraphy of Mesozoic and Cenozoic European Basins, CNRS-IFP, Paris.

Vandenberghe, N., Laga, P., Vandormael, C. \& Elewaut, E. 1988. The geophysical log correlations in the Ieper Clay sections in Belgium. In Dupuis, C., De Coninck, J. \& Steurbaut, E. (Eds), The Ypresian stratotype. Bulletin de la Societe Belge de Géologie, 97: facs. 3-4: 437-440, 8 plates.

Van Wagoner, J. C., Posamentier, H. W., Mitchum, R. M. Jr., Vail, P. R., Sarg, J. F, Loutit, T. S. \& Hardenbol, J. 1988. An overview of the fundamentals of sequence stratigraphy and key definitions. In Wilgus, C. K., Hastings, B. S., Kendall, G. C. St. C., Posamentier, H. W., Ross, C. A. \& Van Wagoner, J. C. (Eds), Sea-level changes: An Integrated Approach. SEPM, Tulsa, Special Publication 42: 125-154.

Vining, B. A., loannides, N. S. \& Pickering, K. T. 1993. Stratigraphic relationships of some tertiary lowstand deposits in the Central North Sea. In Parker, J. R. (Ed.), Petroleum Geology of Northwest Europe: Proceedings of the 4th Conference, 17-30, Geological Society, London.

Vinken, R. (Ed.). 1988. The Northwest European Tertiary Basin. Results of the International Geologic Correlation Programme Project No. 124. Geologisches Jahrbuch, Hannover A100: 7-508.

Walker, R. G. 1978. Deep-water sandstone facies and ancient submarine fans: Models for exploration for stratigraphic traps. AAPG Bulletin, 62: 932-966. 